\title{
Lung Adenocarcinoma in Never Smokers: Problems of Primary Prevention from Aspects of Susceptible Genes and Carcinogens
}

\author{
ISAO OKAZAKI ${ }^{1,2}$, SHIGEMI ISHIKAWA ${ }^{3}$, WATARU ANDO ${ }^{4}$ and YASUNORI SOHARA ${ }^{5}$ \\ ${ }^{1}$ Department of Internal Medicine, Sanno Hospital, International University of Health and Welfare, Tokyo, Japan; \\ Departments of ${ }^{2}$ Internal Medicine and ${ }^{3}$ Chest Surgery, \\ International University of Health and Welfare Hospital, Nasushiobara, Japan; \\ ${ }^{4}$ Department of Clinical Pharmacy, Center for Clinical Pharmacy and Sciences, \\ School of Pharmacy, Kitasato University, Tokyo, Japan; \\ ${ }^{5}$ Department of Chest Surgery,Saitama Prefecture Central Hospital, Okegawa, Japan
}

\begin{abstract}
Global statistics estimate that approximately 25\% of patients with lung cancer are never smokers. We suggest that genes related to susceptibility to metabolic syndrome were present among those related to susceptibility to lung adenocarcinoma $(A C)$ in never smokers. There are many questions concerning lung $A C$ in never smokers, which is increasing in incidence, with female predominance, good prognosis, unique genes related to susceptibility and good response to treatment with specific agents. The purpose of this review was to investigate the carcinogenesis of lung $A C$ in never smokers focusing on genes related to susceptibility to lung $A C$ and carcinogens, including environmental factors. In order to clarify the carcinogenesis of lung $A C$ in never smokers, the definition of never smokers, survey of environmental tobacco smoke, the presence of the physical characteristics of metabolic syndrome, and other carcinogens should be investigated for primary prevention of lung AC.
\end{abstract}

Lung cancer was the leading cause of death in developed countries in 2012 in both males and females, and the leading cause in less developed countries in males and the second cause in females (1). Lung cancer is classified into two morphological groups, small cell lung cancer (SCLC) and

This article is freely accessible online.

Correspondence to: Dr. Isao Okazaki, Department of Internal Medicine, Sanno Hospital, International University of Health and Welfare (IUHW), Minato-ku, Tokyo 107-0052, Japan. Tel: +81 334023151,e-mail: iokazaki@iuhw.ac.jp

Key Words: Never smoker, lung adenocarcinoma, environmental tobacco smoke (ETS), susceptible gene, metabolic syndrome, review. non-small cell lung cancer (NSCLC). NSCLC includes squamous cell lung cancer (SC) and adenocarcinoma (AC). Lung $\mathrm{AC}$ is on the rise in both sexes, especially women, although the number is not as high as among men, in both developed and developing countries (2). Lung AC is associated with life-style throughout the world $(1,3)$.

Islami et al. reported that global incidence and mortality rates of lung cancer are still closely associated with smoking prevalence (4). However, high-income countries have shown remarkable decrease in smoking in both males and females (4). Parkin et al. reported that $15 \%$ of lung cancer cases in men and $53 \%$ in women are not attributable to smoking, and approximately $25 \%$ of patients with lung cancer were never smokers, according to global statistics in 2002 (5). This was a very shocking report. A review article by Sun, et al. (6) and others (7-10) reported that never-smoker patients with lung AC were predominantly female $(6,10)$, were significantly younger $(7,8)$ and had better prognosis $(6,7,10-12)$, with especially good response to treatment with epidermal growth factor receptor-tyrosine kinase inhibitors (EGFR-TKIs) (7, 13-15). Such patients were frequently Asian females $(4,16)$.

We previously wrote a review on genes related to susceptibility to lung AC in never smokers and demonstrated that genes associated with metabolic syndrome were present among these (17). Many questions arose, e.g. whether lung AC may be a different disease $(6,7)$, whether it may involve different genes (8), why female predisposition is present, whether the number of patients continues to increase (16), and why there are so many patients with $\mathrm{AC}$ among never smokers with $\operatorname{NSCLC}(6,16,18)$. For primary prevention, it is most important to clarify the mechanism of carcinogenesis, especially to identify carcinogens related to genes susceptibility to lung cancer. Moreover, it should also be elucidated whether and how metabolic syndrome plays a role in these patients (17). 
Concerning lung carcinogenesis in never smokers, environmental tobacco smoke (ETS) at home, work and other places have been supposed to be the cause of lung cancer in never smokers $(4,19-24)$. If never smokers have been exposed to ETS, it may act as a trigger, converting stem cells into cancer cells in the lung (25) with involvement of metabolic syndrome (26). Besides ETS, reported carcinogens include radon (27-29), cooking oil vapor $(9,30)$, indoor coal burning, hormonal factors (after hormonal replacement therapy) $(6,8,9)$, occupational chemical exposure including asbestos/heavy metals $(8)$, infectious factors $(31,32)$, and air pollution (8).

The purpose of the present study was to clarify the carcinogenesis of lung AC in never smokers from the viewpoints of both genes related to susceptibility, environmental factors and lifestyle. It is necessary to clarify why lung $\mathrm{AC}$ is increasing in Asian women never smokers $(15,29)$. Finally this review shows the interrelation between genes related to susceptibililty and suspected carcinogens from original articles on lung AC in never smokers, and discusses a primary prevention strategy for lung cancer in never smokers.

\section{Selection of Bibliography}

The articles cited in this review dated before 2000 were selected from review articles. Original articles after 2000 sought from PubMed were screened by us. The key words used in the search were as follows: lung cancer, lung AC, never smoker, NSCLC, incidence rate of global lung cancer, mortality rate of lung cancer, smoking prevalence, genes susceptible to lung cancer, and genes susceptible to lung AC. Of the articles published after 2000 we selected those we considered to be most important and appropriate for this study. The purpose of this review was to investigate the carcinogenesis of lung AC in never smokers focusing on genes related to susceptibility and suspected carcinogens, including environmental factors, in order to improve primary prevention of lung AC.

\section{Original Articles on Genes Related to Susceptibility to Lung AC in Never Smokers}

Thirty-one original articles listed in our previous review (17) were examined once again from the following standpoints: the hypothesis or purpose stated by the authors, the genes they had investigated, the study style used, the definition of never smokers, and the etiology of lung AC they analyzed such as ETS. Among these, the study hypothesis was considered the most important. If the authors had found genes related to susceptibility to lung AC and these genes were analyzed by the grade of heavy smoking but did not include discussion on never smokers, we deleted these articles from the list of originals in the present study. We focused more precisely on genes related to susceptibility to lung $\mathrm{AC}$ in never smokers (Table I).

\section{Classical Genes}

The hypothesis stated in the original articles on classical genes (20,33-43) is as follows: exposure of never smokers to ETS resulted in lung AC, hence the genes affected in these cases are the same as those seen in the tobacco-related cases (33-36). The relative risk of the genes suspected in patients with lung AC exposed to ETS was higher than the frequency of suspected genes in patients with lung AC without exposure to ETS (Table I). The slow and the fast genotypes among the polymorphisms of $N$-acetyltransferase 2 (NAT2) were shown to be related to the risk of lung cancer among women never smokers (37). NAT2 participates in the detoxification of aromatic amines. The authors took into consideration exposure to cooking oil fumes among never smoker women who developed lung cancer.

The tumor suppressor genes, TP53 and, TP63 may be involved in carcinogenesis of lung $\mathrm{AC}$ in female never smokers $(38,39)$, although TP53 mutation has been reported in smokers with lung SC (17). These two reports $(38,39)$ did not describe the survey methods regarding ETS. Of course the authors understood the possibility of ETS, or other environmental risk factors, such as exposure to combustion products of indoor heating and cooking solid fuel and cooking oil fumes, as possible etiologies (38). Zhang et al. (39) introduced studies by Cianchi et al. (68) and Yao and Rahman (69), reporting that exposure to external carcinogens, including cigarette smoking, infectious agents, and dietary carcinogens, can result in inflammation and play a role in tumor development, but ETS in their cases was not analyzed because it was not their purpose. The purpose of their studies was to discover novel genes. DNA-repair genes were investigated in never smokers (40-43) and the authors strongly suggested the possibility of ETS $(41,42)$ or cooking oil fumes (40) as suspected carcinogens.

\section{Susceptible Genes Found by Genome-wide Association Study (GWAS)}

Nicotine acetylcholine esterase [cholinergic receptor nicotinic alpha (CHRNA)] genes found by GWAS for association with lung cancer reported by Amos et al. (70), Hung et al. (71) and Thorgeirsson et al. (72) indicated the association of chromosome $15 \mathrm{q}$ variants for CHRNA (rs16969968 and rs8034191) and risk of lung cancer with odds ratios (ORs) between 1.30 and 1.32. This was not found in patients with lung AC in Asia by Wu et al. (44), who identified four novel single-nucleotide polymorphisms (SNPs) for CHRNA3 (rs2036534c $>\mathrm{T}$, rs667282C $>\mathrm{T}$, 


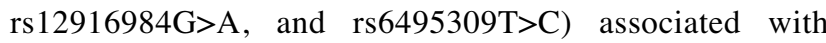
significantly increased lung cancer risk and smoking behavior. Shiraishi et al. reported CHRNA SNPs to be associated with lung cancer susceptibility in a small subset of the Japanese population in a smoking-independent manner (45). These two reports from Asia did not focus on never smokers, and the results regarding smoking habits were very different between the reports, stressing the vital importance of the survey method used when analyzing smoking habits in patients as well as in controls (Table I). Wang et al. found no evidence of association between $6 \mathrm{p} 21.33$ or $15 \mathrm{q} 25.1$ variation and risk of lung AC in never smokers (47), and this finding was widely accepted in an article written by authors of 69 Institutions (73).

Telomerase reverse transpeptidase (TERT)-Cleft lip and palate transmembrane 1-like protein $(C L P T M 1 L)$ variants may be involved in lung $\mathrm{AC}$ as a gene related to lung $\mathrm{AC}$ in never smokers (46-51) (Table I). The survey method regarding ETS was not described in this excellent and important article (Table I). The 5p15.33 region was associated significantly with lung AC in Asian female never smokers (48). Landi et al. revealed that 5p15.33 rs2736100 (TERT) was associated with risk of AC [odds ratio $(\mathrm{OR})=1.23$ ] (49). Jin et al. confirmed that 5p15.33, especially in the TERT gene, may also predispose to susceptibility to lung AC in Chinese female never smokers (50). Fine-mapping analysis of genetic variants in the 5 p15.33 region conducted by Pande et al. revealed four SNPs associated with lung cancer risk (46): rs4975538, which is an intronic SNP in TERT, rs451360 and rs370348, which are intronic SNPs in CLPTMIL, and rs4975615, which is in the intergenic region between the two genes. However, these excellent articles did not discuss any association with ETS among never smokers.

Lan et al. made the extremely important finding that the strongest association signal, rs7086803 at 10q25.2, located at intron 7 of the vesicle transport through interaction with t-SNAREs homologue 1A gene (VT11A) gene was implicated in lung carcinogenesis (52). VTl1A is involved in ACRP30-containing vesicles in adipocytes, and lower amounts of VTl1A in cultured adipocytes can inhibit adiponectin secretion (74). However, it is not clear how this international team defined the term never smokers or how several thousand cases and controls were surveyed for smoking habits.

Li et al. demonstrated a strong correlation between the transcription level of the gene glypican-5 (GPC5) and genotypes of the replicated SNP (rs2352028 at 13q31.3) in 77 non-tumor lung tissue samples, and the expression levels of GPC5 in the matched lung AC tissue were lower by half than in normal tissues (54). The main function of membraneattached glypican is to regulate the signaling pathway of wingless transformation, hedgehog, fibroblast growth factors, and bone morphogenetic proteins (75). The authors showed that down-regulation of GPC5 contributes to the development of lung cancer in never smokers. Their results were discussed from the viewpoints of former smokers and never smokers who had quit smoking (54) in relation to ETS exposure in never smokers (76). Landi et al. did not agree with this observation (55). However, the study by Li et al. (54) opened the way to a new epidemiological approach to clarify the interrelationships between the susceptible genes found by GWAS and carcinogens in ETS.

Tessema et al. reported that never smokers with primary $\mathrm{AC}$ had a significantly higher prevalence of methylation of tumor necrosis factor receptor superfamily member $10 \mathrm{C}$ (TNFRSF10C), basic helix-loop-helix (bHLH) transcription factor 5 (BHLHB5) and boule-like RNA-binding protein (BOLL) (regulating meiotic $\mathrm{G}_{2} / \mathrm{M}$ transition) than current and former smokers (56). Genotypes of C3ORF21, which plays an important role in the formation of NOTCH EGF repeats, were nominally associated with a reduced risk of lung AC among never smokers (39). Another locus, 18p11.22, near the adenomatous polyposis coli downregulated 1 (APCDD1), $\mathrm{N}$-ethylmaleimide-sensitive factor attachment protein gamma $(N A P G)$ and family with sequence similarity 38 , member B $(F A M 38 B)$ genes was reported in Korean never smokers with NSCLC by Ahn et al. (53). These findings for never smokers are very important, but the survey method of smoking was not sufficiently described.

\section{Driver Genes}

Driver genes are of interest as genes related to susceptibility to lung AC in Asian women never smokers from the standpoints of signal transduction for cell proliferation, survival migration and angiogenesis, as well as good treatment response to EGFR-TKIs if EGFR mutation was present (57-64) (Table I). Driver genes include mutations of $E G F R$, Kirsten rat sarcoma viral oncogene (KRAS), protooncogene B-Raf (BRAF), phosphatidylinositol-4,5bisphosphate 3-kinase, catalytic subunit alpha (PIK3CA), and fusion of echinoderm microtubule-associated protein-like 4 (EML4) and the intracellular signaling portion of the anaplastic lymphoma kinase (ALK) protein $(E M L 4-A L K)$.

Among never smokers with AC, the frequency of EGFR mutation was reported to be $42 \sim 50 \%$ in Asia $(57,58,60)$, and $55 \%$ in those of European descent (63), while the frequencies of those with fusion of EML4-ALK, PTEN, PIK3CA, C-MET, $K R A S$, STK11, and BRAF were 9.3\%, 9.1\%, 5.2\%, 4.8\%, $4.5 \%, 2.7 \%$, and $1.9 \%$, respectively (57). Among smoker patients with $\mathrm{AC}$, the frequency of $E G F R$ mutation was reported to be $22.0 \%$ (57) or $10 \%$ to $20 \%$ (60), while the mutation frequency of STK11 was $19.0 \%$, and of KRAS was $12.0 \%$ (57). That is, never smokers with lung AC showed 
Table I. List of publications selected for the present review on genes related to lung adenocarcinoma (AC) in never smokers.

\begin{tabular}{|c|c|c|c|c|c|}
\hline Author(s) (Ref. no.) & $\begin{array}{l}\text { Hypothesis } \\
\text { (purpose) }\end{array}$ & $\begin{array}{c}\text { Gene } \\
\text { (cases/controls) }\end{array}$ & $\begin{array}{l}\text { Country/ } \\
\text { city/year }\end{array}$ & $\begin{array}{l}\text { Definition } \\
\text { of NS }\end{array}$ & ETS Consideration \\
\hline
\end{tabular}

1. Classical genes

CYP1A1 polymorphisms

Yoon et al. (33) Low dose carcinogen exposure in never smokers

\section{CYP1B1 Leu432Val with CYP1A1 Ile462Val $(213 / 213) \mathrm{OR}=2.16$}

GST

polymorphisms

Bennett et al. (34) Never-smoking women exposed to ETS

Wenzlaff et al. (20)

Low levels of household ETS exposure in never smokers.

Hung et al. (35)

Malats et al. (36)

NAT2

fast acetylator genotype

Chiou et al. (37) A correlation between cooking oil fumes and female lung cancer has been revealed.

Tumor suppressor genes: TP53, TP63

Hosgood et al. (38) To determine the risk of lung AC in Asian female never smokers.

Zhang et al. (39) TP63 SNPs and C3orf21 SNPs were genes susceptible for lung $\mathrm{AD}$ in never smokers in China.

DNA damage repair genes

Shen et al. (40) To clarify the role of ATM gene in lung AC in Chinese female non-smokers.
GSTM1 null (no ETS 55/ETS 51 in never smoker women) $\mathrm{OR}=2.6$ GST M1 null (20 or years more household ETS in never smokers).

$$
\mathrm{OR}=2.3
$$

\section{CYP1A1 Ile 462 Val}

(a pooled analysis

14 case-control studies, 302 cases/1631 controls) $\mathrm{OR}=2.99$

$G S T M 1 * 2$ (null)

(122 nonsmoking cases/

121 nonsmoking controls) $\mathrm{OR}=1.5$ (ETS),

$\mathrm{OR}=3.1$ (indoor wood combustion)

Polymorphisms of NAT2 responsible for the metabolism of heterocyclic amines (162 cases/208 controls) $\mathrm{OR}=2.44$

TP63 SNPs, rs 10937405 $(3,467 / 3,787)$

allelic risk 0.80

TP63 SNPs were not but C3ORF21 SNPs were associated with susceptibility to

NSCLC in Chinese never smokers. C3ORF 21 and TP63 $(200 / 200)$ OR $(C 3 O R F 21)=$ 0.707 and OR (TP63) 1.227.

ATM rs189037 AA genotype compared with those carrying the GA or GG genotype (487 cases/ 516 controls) $\mathrm{OR}=1.89$ (cooking oil fumes)
Missouri/ 1992-1995

Missouri/Detroit/ 1990-2005

USA, Norway, Finland, Sweden, Germany, Hungary,

Slovakia, Poland, lives, varied UK/1988-1997 slightly among the studies.

Eight countries/? Pure never smokers.

Veterans General Hospital-Taichung and Chung Shan Med. University Hospital/Taiwan/ before 2007?

Taiwan, China, South Korea, Singapore/ before 2010?

Zejiang Cancer Hospital/ China/?

Liaoning Cancer Yes* ospital, China/Jan 2002-Nov. 2012
Not described

Not described

Never smoked
Smoking habits of family members, environmental factors obtained by a personal interview (trained personnel).

Interview by trained personnel.

Trained interviewer conducted telephone interview. Participants were asked about ETS exposure at home and workplace, including hours and years of exposure.

(Collected studies not described in detail)

Information on demographics and environmental exposures was obtained through a personal interview using a standard questionnaire.

Interview

Collected studies (not described)

Not described
Information on demographics and environmental exposures was obtained by trained interviewers. 
Table I. Continued

\begin{tabular}{|c|c|c|c|c|c|}
\hline Author(s) (Ref. no.) & $\begin{array}{l}\text { Hypothesis } \\
\text { (purpose) }\end{array}$ & $\begin{array}{c}\text { Gene } \\
\text { (cases/controls) }\end{array}$ & $\begin{array}{l}\text { Country/ } \\
\text { city/year }\end{array}$ & $\begin{array}{l}\text { Definition } \\
\text { of NS }\end{array}$ & ETS Consideration \\
\hline Bock et al. (41) & $\begin{array}{l}\text { Risk reduction } \\
\text { due to procarcinogen } \\
\text { activating of } N Q O 1 .\end{array}$ & $\begin{array}{c}\text { NQO1 } T \text { allele }(161 / 173) \\
\text { OR=0.48 and } \\
\text { OR }=0.57 \text { (ETS) }\end{array}$ & $\begin{array}{l}\text { Detroit/diagnosed } \\
\text { in 1984-87; } \\
\text { after } 1990\end{array}$ & Yes* & $\begin{array}{l}\text { The overall interview } \\
\text { response rate for cases was } 66.1 \%\end{array}$ \\
\hline Cohet et al. (42) & $\begin{array}{l}\text { Second-hand smoke } \\
\text { and repair of DNA } \\
\text { damage in never smokers. }\end{array}$ & $\begin{array}{c}\text { Exon } 5 \text { of the AGT } \\
\text { gene }(136 / 133) \\
\text { OR=2.05 and } \\
\text { OR=1.95 (ETS) }\end{array}$ & $\begin{array}{l}\text { Eight countries/ } \\
1992-1944\end{array}$ & Yes* & Not sufficient \\
\hline Pulling et al. (43) & $\begin{array}{l}\text { The prevalence for } \\
O^{6} \text {-methylguanine- } \\
\text { DNA methyltransferase } \\
\text { (MGMT) promoter } \\
\text { methylation and } \\
\text { K-ras mutation. }\end{array}$ & $\begin{array}{c}\text { Promoter } \\
\text { hypermethylation } \\
\text { of } M G M T \\
\text { (157 smokers/34 } \\
\text { former uranium miners/ } \\
46 \text { never smokers) }\end{array}$ & $\begin{array}{l}\text { New Mexico } \\
\text { Tumor Registry/? }\end{array}$ & Yes* & $\begin{array}{l}\text { Multi-center studies } \\
\text { (not described) }\end{array}$ \\
\hline \multicolumn{6}{|c|}{$\begin{array}{l}\text { 2. Susceptible Genes Found by Genome-Wide } \\
\text { Association Studies } \\
\text { 15q25: Nicotine acetylcholine esterase genes }\end{array}$} \\
\hline Wu et al. (44) & $\begin{array}{c}\text { To identify other } \\
\text { variants on } 15 \mathrm{q} 25 \\
\text { associated with lung } \\
\text { cancer susceptibility } \\
\text { in Chinese. }\end{array}$ & $\begin{array}{c}\text { rs2036534C }>\mathrm{T}, \\
\mathrm{rs667282 \textrm {C } >} \\
\mathrm{T}, \mathrm{rs} 12910984 \mathrm{G}>\mathrm{A}, \\
\mathrm{rs6495309 \textrm {T } >} \\
\mathrm{C}(576 / 576 ; 2,989 / \\
2,880 ; 2,221 / 2112) \\
\mathrm{OR}=1.42, \text { and } 1.40, \\
\text { respectively in } \\
\text { never smokers. }\end{array}$ & $\begin{array}{l}\text { Beijing/1997-2008; } \\
\text { Jiangsu/2002-2008 }\end{array}$ & $\begin{array}{l}\text { Less than } 1 \\
\text { cigarette } \\
\text { per day and } \\
<1 \text { y in } \\
\text { their } \\
\text { lifetime } \\
\text { nonsmoker. }\end{array}$ & Through interviews \\
\hline Shiraishi et al. (45) & $\begin{array}{l}\text { To obtain further } \\
\text { information on } \\
\text { CHRNA SNPs in } \\
\text { lung cancer risk. }\end{array}$ & $\begin{array}{l}\text { Haplotype of minor } \\
\text { alleles for three } \\
\text { SNPs rs8034190, } \\
\text { rs16969968 and } \\
\text { rs1051730 (1250/936) } \\
\text { OR=2.3 in Japanese. }\end{array}$ & Japan/2009. & $\begin{array}{l}\text { Non-smokers } \\
\text { were defined } \\
\text { as those who } \\
\text { had not } \\
\text { smoking habit. }\end{array}$ & $\begin{array}{l}\text { Smoking history was } \\
\text { obtained via interview } \\
\text { using a questionnaire. } \\
\text { Smoking exposure was } \\
\text { expressed in "pack-years". }\end{array}$ \\
\hline \multicolumn{6}{|c|}{ 5p15: TERT and CLPTM1L } \\
\hline Pande et al. (46) & $\begin{array}{l}\text { To analyze } 215 \\
\text { SNPs across TERT } \\
\text { and } C L P T M 1 L \text {. }\end{array}$ & $\begin{array}{c}215 \mathrm{SNPs} \text { at } 5 \mathrm{p} 15.33 \\
(1,681 / 1,235) \text { rs } 451360 \\
\mathrm{OR}=0.62 \text { in never smokers. }\end{array}$ & Texas/1995-? & Not described & Not described \\
\hline Wang et al. (47) & $\begin{array}{l}\text { To examine if variation } \\
\text { at } 5 \mathrm{p} 15.33 \text { (TERT- } \\
C L P T M I L), 6 \mathrm{p} 21.33 \\
\text { and } 15 \mathrm{q} 25.1 \text { (CHRNA5- } \\
\text { CHRNA3) influences } \\
\text { the risk of lung cancer } \\
\text { in never smokers. }\end{array}$ & $\begin{array}{c}\text { 5p15.33-TERT } \\
\text { (rs2736100), 5p15.33- } \\
\text { CLPTMIL (rs4975616), } \\
\text { 6p21.33-BAT3 } \\
\text { (rs317582), 15q25.1- } \\
\text { CHRNA3 (rs8042374), } \\
\text { and 15q25.1-CHRNA3 } \\
\text { (rs12914385) }(239 / 553)\end{array}$ & $\begin{array}{l}\text { Genetic Lung } \\
\text { Cancer } \\
\text { Predisposition } \\
\text { Study (2008) }\end{array}$ & Yes* & Not described \\
\hline Hsiung et al. (48) & $\begin{array}{c}\text { To investigate } 5 \mathrm{p} 15.33 \\
\text { in lung cancer among } \\
\text { never smoker } \\
\text { Asian women by GWAS. }\end{array}$ & $\begin{array}{c}\mathrm{rs} 2736100 \\
(1,164 / 1,736) \\
\text { Allelic risk } 1.62\end{array}$ & $\begin{array}{l}\text { Seven studies/ } \\
\text { Taiwan/? }\end{array}$ & Not described & $\begin{array}{l}\text { Seven studies } \\
\text { (not described) }\end{array}$ \\
\hline Landi et al. (49) & $\begin{array}{l}\text { A GWAS of lung cancer } \\
\text { and its major } \\
\text { histological types. }\end{array}$ & $\begin{array}{l}\text { rs2736100 }(T E R T) \\
(5739 / 5848) \text { OR=1.3 } \\
\text { in adenocarcinoma. }\end{array}$ & $\begin{array}{l}\text { NCI GWAS/10 } \\
\text { European studies } \\
\quad / 1985-2001\end{array}$ & Not described & $\begin{array}{l}\text { Eleven studies } \\
\text { (not described) }\end{array}$ \\
\hline Jin et al. (50) & $\begin{array}{l}\text { To test TERT and } \\
\text { CLPTM1L in } \\
\text { a Chinese Population. }\end{array}$ & $\begin{array}{c}5 \mathrm{p} 15.33(\mathrm{rs} 402710 \mathrm{C} / \mathrm{T} \\
\text { and } \mathrm{rs} 2736100 \mathrm{C}) \\
(1,221 / 1,344), \\
\mathrm{OR}=1.09, \text { and } 1.59, \\
\text { respectively. }\end{array}$ & Nanjing/2003-? & Not described & $\begin{array}{c}\text { Face-to-face interviews } \\
\text { to obtain exposure } \\
\text { information (e.g. } \\
\text { smoking status) }\end{array}$ \\
\hline McKay et al. (51) & $\begin{array}{l}\text { A GWAS of lung } \\
\text { cancer detected two } \\
\text { genes, TERT and } \\
\text { CLPTM1L. }\end{array}$ & $\begin{array}{l}5 \mathrm{p} 15.33 \text { (rs } 402710 \\
\text { and rs } 2736100) \\
(3,259 / 4159 ; 2,899 / \\
5,573) \text { OR=1.25, and } \\
1.15, \text { respectively. }\end{array}$ & $\begin{array}{l}\text { Toronto, HUNT2/ } \\
\text { Troms } \phi, \text { CARET/? }\end{array}$ & Not described & $\begin{array}{l}\text { The survey of ETS } \\
\text { was not described? } \\
\text { Suppl online }\end{array}$ \\
\hline
\end{tabular}


Table I. Continued

\begin{tabular}{|c|c|c|c|c|c|}
\hline Author(s) (Ref. no.) & $\begin{array}{c}\text { Hypothesis } \\
\text { (purpose) }\end{array}$ & $\begin{array}{c}\text { Gene } \\
\text { (cases/controls) }\end{array}$ & $\begin{array}{l}\text { Country/ } \\
\text { city/year }\end{array}$ & $\begin{array}{l}\text { Definition } \\
\text { of NS }\end{array}$ & ETS Consideration \\
\hline \multicolumn{6}{|l|}{$V T L 1 A$} \\
\hline Lan et al. (52) & $\begin{array}{l}\text { To identify common } \\
\text { genetic variants susceptible } \\
\text { to lung cancer in never } \\
\text { smoker Asian women. }\end{array}$ & $\begin{array}{c}10 \mathrm{q} 25.2(\mathrm{rs} 7086803) \\
(5,510 / 4,544) \\
\mathrm{OR}=1.32\end{array}$ & $\begin{array}{c}\text { China, South Korea, } \\
\text { Japan, Singapore, } \\
\text { Taiwan and Hong } \\
\text { Kong/before 2010? }\end{array}$ & $\begin{array}{l}\text { Not described } \\
\text { (online } \\
\text { version?) }\end{array}$ & $\begin{array}{l}\text { Not described } \\
\text { (online?) }\end{array}$ \\
\hline \multicolumn{6}{|c|}{ Other Genes Found by GWAS } \\
\hline Zhang et al. (39) & $\begin{array}{c}\text { Do environmental agents } \\
\text { affect genetic } \\
\text { polymorphisms? }\end{array}$ & $\begin{array}{c}\text { TP63 SNPs were } \\
\text { not but } C 3 O R F 21 \\
\text { SNPs were associated } \\
\text { with susceptibility to } \\
\text { NSCLC in a Chinese } \\
\text { population. C3ORF21 } \\
\text { and } T P 63(200 / 200)\end{array}$ & China/Zejiang/? & Not described & Not described \\
\hline Ahn et al. (53) & $\begin{array}{l}\text { To identify genetic } \\
\text { loci associated with } \\
\text { susceptibility of lung } \\
\text { cancer in never } \\
\text { smokers in Korea. }\end{array}$ & $\begin{array}{l}\text { Among the } 44 \text { validation } \\
\text { SNPs, two (rs11080466 } \\
\text { and rs } 11663246) \\
\text { near } A P C D D 1, N A P G \\
\text { FAM38B }(446 / 497)\end{array}$ & $\begin{array}{l}\text { Samsung Medical } \\
\text { Center/2009 }\end{array}$ & Yes* & Not described \\
\hline Li et al. (54) & $\begin{array}{c}\text { To unravel the genetic } \\
\text { basis of lung cancer, } \\
\text { glypican-5. }\end{array}$ & $\begin{array}{c}\text { Among } 44 \text { top } \\
\text { candidate SNPs, } \\
13 \text { p31.3 (rs2352028) } \\
(377 / 377) \text { OR=1.46 }\end{array}$ & $\begin{array}{c}\text { Rochester, Texas, } \\
\text { Harvard/? }\end{array}$ & Yes* & $\begin{array}{l}\text { Interview by } \\
\text { trained personels. }\end{array}$ \\
\hline Landi et al. (55) & $\begin{array}{l}\text { To replicate glypican-5 } \\
\text { study by Y. Li et al. } \\
\text { (54) on } 754 \text { never smoker } \\
\text { lung cancer cases and } \\
10580 \text { controls from } \\
\text { seven GWAS studies. }\end{array}$ & $\begin{array}{c}13 \mathrm{p} 31.3(\mathrm{rs} 2352028) \\
(754 / 10580) \\
\mathrm{OR}=1.04\end{array}$ & $\begin{array}{l}\text { USA, France, } \\
\text { Germany, } \\
\text { UK, Iceland/? }\end{array}$ & Not described & Not described \\
\hline Tessema et al. (56) & $\begin{array}{l}\text { To reveal the } \\
\text { involvement of promoter } \\
\text { hypermethylation } \\
\text { in lung AD. }\end{array}$ & $\begin{array}{c}\text { Prevalence of } \\
\text { methylation of } \\
\text { TNFRSF10C, BHLHBS, } \\
\text { and BOLL (175 AD) }\end{array}$ & $\begin{array}{l}\text { Johns Hopkins } \\
\text { and Mayo } \\
\text { Clinic/? }\end{array}$ & Not described & Not described \\
\hline \multicolumn{6}{|c|}{ 3. Driver Genes: $E G F R, K R A S, B R A F, P I K 3 C A$, and $E M L 4-A L K$} \\
\hline An et al. (57) & $\begin{array}{l}\text { The tyrosine kinase } \\
\text { inhibitors targeting } \\
E G F R \text { is the first line } \\
\text { therapy for patients } \\
\text { with } N S C L C \text { related with } \\
\text { the mechanism of } E G F R \\
\text { exon } 20 T 790 M \text { mutation. }\end{array}$ & $\begin{array}{c}\text { Driver gene } \\
\text { alterations (524) }\end{array}$ & $\begin{array}{l}\text { China/Guangdong } \\
\text { (2007-2009) }\end{array}$ & Yes* & Not described \\
\hline \multicolumn{6}{|l|}{ EGFR mutation } \\
\hline Li et al. (58) & $\begin{array}{c}\text { To reveal the prevalence } \\
\text { of } E M L 4-A L K, \\
E G F R \text { status and } \\
K R A S \text { mutation. }\end{array}$ & $\begin{array}{l}208 \text { NSCLC } \\
\text { patients }\end{array}$ & $\begin{array}{c}\text { China/Tianjin } \\
\text { Medical } \\
\text { University/? }\end{array}$ & Not described & Not described \\
\hline Ren et al. (59) & $\begin{array}{l}\text { To determine the } \\
\text { distribution of known } \\
\text { oncogenic driver } \\
\text { mutation in female } \\
\text { non-smoker Asian } \\
\text { patients with lung AC. }\end{array}$ & $\begin{array}{c}396 \text { Female non-smoker } \\
\text { patients with AC; } \\
\text { Oncogenic mutation } \\
(82.7 \%)\end{array}$ & $\begin{array}{c}\text { Shanghai/Tongi } \\
\text { University/? }\end{array}$ & Yes* & Not described \\
\hline Lee et al. (60) & $\begin{array}{l}\text { To clarify the effect } \\
\text { of ETS on } \\
\text { EGFR mutation. }\end{array}$ & $\begin{array}{l}\text { The nucleotide sequences } \\
\text { of exons } 18 \text { to } 21 \text { on } \\
\text { EGFR gene (179 cases) } \\
\text { EGFR mutation (ETS } \\
38.5 \% \text { vs. Never } 61.4 \%)\end{array}$ & $\begin{array}{l}\text { Yonsei University } \\
\text { College of Med, } \\
\text { Seoul/June } \\
\text { 2006-Dec } 2008\end{array}$ & Yes* & $\begin{array}{l}\text { Interviewed by } \\
\text { trained interviewers. }\end{array}$ \\
\hline
\end{tabular}


Table I. Continued

\begin{tabular}{|c|c|c|c|c|c|}
\hline Author(s) (Ref. no.) & $\begin{array}{l}\text { Hypothesis } \\
\text { (purpose) }\end{array}$ & $\begin{array}{c}\text { Gene } \\
\text { (cases/controls) }\end{array}$ & $\begin{array}{l}\text { Country/ } \\
\text { city/year }\end{array}$ & $\begin{array}{l}\text { Definition } \\
\text { of NS }\end{array}$ & ETS Consideration \\
\hline Jou et al. (61) & $\begin{array}{l}\text { Association of an } \\
E G F R \text { intron 1 SNP } \\
\text { with never-smoking } \\
\text { female lung AC }\end{array}$ & $\begin{array}{c}\text { SNP } 8227 \mathrm{G}>\mathrm{A} \text { (rs763317) } \\
(730 / 730) \text { OR=1.23 } \\
\text { (for GA genotype), } \\
\mathrm{OR}=3.52 \text { (for AA genotype), } \\
\mathrm{OR}=1.35 \text { (adenocarcinoma). } \\
\text { The rare alle of } \\
8227 \mathrm{G}>\mathrm{A} \text { (haplotype) } \\
\mathrm{OR}=2.81\end{array}$ & $\begin{array}{c}\text { Taiwan/ } \\
\text { 2002-2004 }\end{array}$ & Not described & $\begin{array}{l}\text { If ETS exposure was present, } \\
\text { mark } 1 \text {, and if not, mark } 0 .\end{array}$ \\
\hline \multicolumn{6}{|c|}{ (25) } \\
\hline Jo et al. (62) & $\begin{array}{c}\text { To determine four } \\
\text { polymorphisms } \\
(-3444 \mathrm{C}>\mathrm{T},-1985 \mathrm{G}>\mathrm{T} \text {, } \\
1655 \mathrm{~A} \mathrm{~A}>\mathrm{G} \text { and } \\
\mathrm{P} 1170 \mathrm{~A} \mathrm{C}>\mathrm{G}) \\
\text { of } H E R-2 \text { gene. }\end{array}$ & $\begin{array}{l}814 \text { Patients with lung } \\
\text { cancer } \mathrm{OR}=2.65 \\
(-3444 \mathrm{C}>\mathrm{T}) \text {, and } \\
\mathrm{OR}=2.38(-1985 \mathrm{G}>\mathrm{T})\end{array}$ & $\begin{array}{l}\text { Seoul/Inha } \\
\text { University/ } \\
2001-2005\end{array}$ & Not described & $\begin{array}{l}\text { Smoking information } \\
\text { was obtained using } \\
\text { questionnaires by } \\
\text { trained interviewers, } \\
\text { but information on } \\
\text { ETS was not described. }\end{array}$ \\
\hline \multicolumn{6}{|c|}{$B R A F$ and PIK3CA } \\
\hline Ren et al. (59) & $\begin{array}{l}\text { To determine the } \\
\text { distribution of known } \\
\text { oncogenic driver mutation } \\
\text { in female non-smoker } \\
\text { Asian patients } \\
\text { with lung AC. }\end{array}$ & $\begin{array}{l}396 \text { Female } \\
\text { non-smoker } \\
\text { AD patients } \\
\text { Driver mutations } \\
1.90 \% \text { BRAF, } \\
1.0 \% \text { PI3K. }\end{array}$ & $\begin{array}{c}\text { Shanghai/ } \\
\text { Tongi University/? }\end{array}$ & Yes* & Not described \\
\hline \multicolumn{6}{|l|}{$E M L 4-A L K$} \\
\hline Jang et al. (63) & $\begin{array}{l}\text { Oncogene fusion } \\
\text { transcripts, EZR-ROS1 } \\
\text { and } K I F 5 B-R E T \text { were } \\
\text { identified between } \\
\text { exons } 1-9 \text { of } S N D 1 \\
\text { and exons } 2 \text { to } 3 \text { ' } \\
\text { end of } B R A F \text {. }\end{array}$ & $\begin{array}{l}\text { Oncogene fusion } \\
\text { transcripts } \\
\text { by RNA-Seq } \\
\text { (89 tumors) }\end{array}$ & $\begin{array}{l}\text { Mayo Clinic/USA/ } \\
\text { Jan 1997-Sep } 2008\end{array}$ & Yes* & $\begin{array}{l}\text { Interviewed by trained } \\
\text { interviewers. }\end{array}$ \\
\hline Li et al. (58) & $\begin{array}{l}\text { To reveal the prevalence } \\
\text { of } E M L 4-A L K \text {, } \\
E G F R \text { status and } \\
\text { KRAS mutation. }\end{array}$ & $\begin{array}{l}208 \text { NSCLC } \\
\text { patients }\end{array}$ & $\begin{array}{l}\text { China/Tianjin } \\
\text { Medical } \\
\text { University/? }\end{array}$ & Not described & Not described \\
\hline \multicolumn{6}{|l|}{$H I F-2 \alpha$} \\
\hline Iwamoto et al. (64) & $\begin{array}{l}\text { To reveal the association } \\
\text { of } E P A S 1 \text { gene } \\
\text { rs } 4953354 \\
\text { in lung cancer }\end{array}$ & $\begin{array}{c}\text { EPAS1 AG } \\
\text { polymorphism } \\
\text { (rs4953354) } \\
\text { (346 patients } / 247 \\
\text { healthy controls) } \\
\text { OR=3.31 (female } \\
\text { never smokers) }\end{array}$ & $\begin{array}{c}\text { Shimane University } \\
\text { Hosp., } \\
\text { Higashi-Hiroshima } \\
\text { Med. Cent., } \\
\text { Hiroshima University } \\
\text { Hosp./2009-2012 }\end{array}$ & Not described & Not described \\
\hline \multicolumn{6}{|c|}{ 4. Genes related to inflammation/innate immunity } \\
\hline Kang et al. (65) & $\begin{array}{l}\text { To identify genetic } \\
\text { factors responsible } \\
\text { for lung cancer. }\end{array}$ & $\begin{array}{c}C S F 1 R \\
(\mathrm{rs} 10079250 \mathrm{~A}>\mathrm{G}) \\
T P 63, C 1 R 1(181 \mathrm{cases} / \\
179 \text { controls; } 596 / 1194) \\
\mathrm{OR}=1.85 \\
(\mathrm{rs} 10079250 \mathrm{~A}>\mathrm{G})\end{array}$ & $\begin{array}{c}\text { Kyngpook } \\
\text { National } \\
\text { University } \\
\text { Daegu, Korea/? }\end{array}$ & Yes* & Not described \\
\hline Kiyohara et al. (66) & $\begin{array}{c}\text { To evaluate the } \\
\text { role of } I L 1 B \\
\text { (rs1143634, 3954C>T) } \\
\text { in lung cancer } \\
\text { patients with a } \\
\text { history of smoking. }\end{array}$ & $\begin{array}{c}\text { IL1B }(\mathrm{rs} 1143634, \\
3954 \mathrm{C}>\mathrm{T})(462 / 379) \\
\mathrm{OR}=2.62(\mathrm{TT}), \\
\text { and adjusted } \\
\mathrm{OR}=3.31(\mathrm{TT})\end{array}$ & $\begin{array}{l}\text { Kyushu } \\
\text { University/ } \\
1996-2008\end{array}$ & $\begin{array}{l}\text { Never } \\
\text { smokers } \\
\text { were defined } \\
\text { as those who } \\
\text { had never } \\
\text { smoked in } \\
\text { their lifetime. }\end{array}$ & $\begin{array}{c}\text { As to ETS, interviewed } \\
\text { by Kiyohara C. }\end{array}$ \\
\hline
\end{tabular}


Table I. Continued

\begin{tabular}{|c|c|c|c|c|c|}
\hline Author(s) (Ref. no.) & $\begin{array}{l}\text { Hypothesis } \\
\text { (purpose) }\end{array}$ & $\begin{array}{c}\text { Gene } \\
\text { (cases/controls) }\end{array}$ & $\begin{array}{l}\text { Country/ } \\
\text { city/year }\end{array}$ & $\begin{array}{c}\text { Definition } \\
\text { of NS }\end{array}$ & ETS Consideration \\
\hline $\begin{array}{l}\text { Olivo-Marston } \\
\text { et al. (67) }\end{array}$ & $\begin{array}{l}\text { Children may be more } \\
\text { susceptible to ETS, } \\
\text { and this susceptibility } \\
\text { may be exacerbated by } \\
\text { alteration in inherited } \\
\text { genetic variants in } \\
\text { innate immunity genes. }\end{array}$ & $\begin{array}{c}M B L 2 \text { (mannose } \\
\text { binding lectin-2) } \\
\text { gene (624 cases/ } \\
348 \text { controls; } \\
172 \text { cases/289 } \\
\text { controls in never } \\
\text { smokers) High MBL } \\
\text { levels OR=2.52 } \\
\text { (NCI-MD study), } \\
\text { and OR=2.78 (Mayo } \\
\text { Clinic study) }\end{array}$ & $\begin{array}{l}\text { National Cancer } \\
\text { Institute- } \\
\text { Maryland } \\
\text { Cancer (NCI- } \\
\text { MD)/Mayo } \\
\text { Clinic Study/ } \\
\text { 1997-2001 }\end{array}$ & Yes* & $\begin{array}{c}\text { ETS during the } \\
\text { past } 30 \text { years was } \\
\text { examined in detail. }\end{array}$ \\
\hline
\end{tabular}

NS: Never smoker; AC, adenocarcinoma; ETS, environmental tobacco smoke; OR, odds ratio; *Yes: Indicates the definition that the never smoker had a lifetime exposure of fewer than 100 cigarettes.

increased EGFR mutation and EMLA-ALK fusion protein. These mutations were at low frequency in smokers, but other mutations were seen in smokers with lung cancer (57). Although some cases showed overlap of EGFR and KRAS mutations, these were generally few in AC (57). The EML4$A L K$ fusion gene has been identified in a small subset of patients with lung AC (58). Ren et al. reported that $82.7 \%$ of lung $\mathrm{AC}$ in Asian female non-smokers showed well-known oncogenic mutations in EGFR, KRAS, HER2, BRAF and $P I K 3 C A$, and a majority of the mutations were mutually exclusive as noted above, except two with EGFR mutation and $B R A F$ mutation, one with EML4-ALK fusion and PIK3CA mutation (59). Li et al. identified seven (among 208 cases; $3.37 \%$ ) patients with the EML4-ALK fusion gene, of whom four had variant 3 , two had variant 1 , and one case had variant 1. Of these cases, six were non-smokers, and five were found among 33 cases of female non-smokers. EML4-ALK translocation was predominant in never smokers with AC (58).

Lung AC with EGFR mutation in never smokers showed somewhat good prognosis (57). The effect of ETS on EGFR mutation was reported in lung cancer in never smokers, and the rate of EGFR mutation among never smokers exposed to ETS was significantly low, as discussed below (60). Moreover, EGFR-TKIs, e.g. gefitinib and erlotinib, have been reported to be associated with high sensitivity to AC in Asian women non-smokers (57-61, 77, 78). Activating EGFR mutation, including 19 in-frame deletions and exon 21 L858R substitutions, have been shown to be the most potent biological predictors of sensitivity to EGFR-TKIs (60). Jou et al. found significant frequency of EGFR intron $1 \mathrm{SNP}$ in Asian female never smoker patients with lung AC, as shown in Table I (61).

Other driver genes, human epidermal growth factor receptor type 2 (HER2) and $B R A F$, have been reported in female never smokers with AC $(62,63)$. Jo et al. found that three SNPs of HER2 (-3444C $>\mathrm{T},-1985 \mathrm{G}>\mathrm{T}$ and $\mathrm{P} 1170 \mathrm{~A} \quad \mathrm{C}>\mathrm{G})$ were significantly frequent in Asian female non-smokers and nondrinker patients with lung AC (62). Suzuki et al. examined HER2 gene mutation in 1,275 patients $(1,055 \mathrm{ACs}, 146 \mathrm{SCs}$, and 74 others) and detected HER2 gene mutation in $46(3.6 \%)$ of all cases. Mutation-positive cases were all ACs, comprising $4.3 \%$ of ACs (79). These positive cases were younger never smokers, with smaller tumor size (79).

Jang et al. found novel fusion transcript formed between exon 1-9 of staphylococcal nuclease domain-containing protein 1 (SND1) and exons 2 to 3 ' end of BRAF (63). This was observed in 3/89 tested tumors and 2/64 never-smoker lung ACs (63). BRAF mutations and their fusion transcripts lead to constitutive activation of Ser/Thr kinase activity and are located downstream of the RAF/MEK/ERK pathway in lung, melanoma, thyroid and colon cancer (63). SND1 is a component of the RNA-induced silencing complex and plays a role as a regulator for transcription of specific mRNAs by mediating RNA interference reported in colon, prostate and liver cancer (63).

\section{Genes Related to Inflammation and Natural Immunity}

Kang et al. used an Affymetrix custom-made GeneChip for finding novel genes related to susceptibility to lung cancer in female never smokers, and found three SNPs involved: colony stimulating factor 1 receptor $(C S F 1 R)$ rs 10079250 A $>\mathrm{G}$, TP63 rs7631358G $>\mathrm{A}$ and core-pressor interacting with RBPJ 1 (C1R1) rs130090791 (65). CSF1R rs10079250 $\mathrm{A}>\mathrm{G}$ exhibited an increased level of phosphorylated c-Jun $\mathrm{NH}(2)$-terminal kinase (JNK), a downstream molecule of the CSF1-CSF1R signaling pathway. They did not analyze genes 
from the viewpoint of ETS. Kiyohara et al. reported that an association of $I L I B$ (rs1143634, $3954 \mathrm{C}>\mathrm{T}$ ) polymorphism with lung cancer was seen in never smokers $(\mathrm{OR}=1.11)$; higher risk was of course observed for smokers $(\mathrm{OR}=2.48)$ (66). Olivo-Marston, et al. reported that ETS exposure during childhood is associated with increased lung cancer risk among never smokers, especially never smokers with the haplotype mannose-binding lectin-2 (MBL2) $(\mathrm{OR}=2.52)$, suggesting alteration in inherited genetic variants of innate immunity genes (67). In these reports, the authors described in detail their surveys of smoking habits.

\section{Definition of Never Smoker and Survey Methods for Smoking Habits}

We sent e-mails with a questionnaire regarding the ETS exposure of never smokers to authors who had published original articles on genes and lung $\mathrm{AC}$ among never smokers in December of 2015. Very few responses were received. The reason for this is easily understandable because the hypothesis or purpose of the original articles was not to clarify carcinogenesis but focus on novel genes. Then, we examined the original articles listed in Table I again.

It is globally accepted that the definition of never smoker is as follows: a never smoker is an individual who has had a lifetime exposure of fewer than 100 cigarettes (University of California at Los Angeles, Harvard, Mayo, and International Agency for Research on Cancer studies) (24). This definition is the same as that of World Health Organization nomenclature (80).

Other definitions such as the Hawaii study (those who smoked fewer than 180 cigarettes in their lifetime), the Seoul study (those who smoked fewer than 200 cigarettes in their lifetime), the Liverpool study (those who never smoked more than 10 cigarettes per week regularly), the CREST study (those who either smoked less than 400 cigarettes in their lifetime or less than one cigarette per day for one year), the Aichi and GenAir studies (those who reported they had never smoked) have been reported (24).

We checked the definitions of never smoker described in original articles on novel susceptibility genes for lung AC in never smokers as shown in Table I, and found that most described never smokers as individuals with a lifetime exposure of fewer than 100 cigarettes.

Regarding the method used to survey the smoking habits of the patients, most authors described that a trained interviewer administered the questions regarding smoking. ETS at home, work or other places has been reported to be the cause of lung cancer in never smokers (19-24; Figure 1). De Andrade et al. showed that from 1997 to 2001, 810 women with lung cancer were interviewed to obtain data including the source, intensity, and duration of ETS exposure (76). In this descriptive study, relationships between smoking history, ETS exposure, and lung cancer histological subtypes were analyzed. Among the 810 patients, 773 (95.4\%) reported personal smoking or ETS exposure, including 170 out of 207 (82\%) never smokers. Among the never smokers with a history of ETS exposure, the mean years of exposure were 27 from smoking spouses, 19 from parents, and 15 from co-workers. For each major subtype of lung cancer (AC, SC, unclassified NSCLC, small cell, or carcinoids) among never smokers, $75-100 \%$ of patients had ETS exposure. Trends for AC, SC and small cell carcinoma were found to be statistically significant using the CochranArmitage Test for Trend I $(p<0.001)$ among never smokers without ETS exposure, never smokers with ETS exposure, former smokers, and current smokers.

Kurahashi et al. reported a population-based prospective study (Cohort I in 1990 and Cohort II in 1993) including 28,414 nonsmoking women aged 40-69 years old, 28,414 nonsmoking women with exposure to ETS from their husband, at the workplace and during childhood (21). Over 13 years of follow-up, 109 cases with lung cancer were diagnosed. Among them 82 had lung AC. The hazard ratio (HR) in women with smoker husbands compared to those with never-smoker husbands was 1.34 , and an association with lung $\mathrm{AC}$ had an HR of 2.03, with a dose-response relationship with the husbands' smoking. Tse et al. demonstrated an association between ETS on lung cancer in nonsmokers using a population-based, case-referent study in Hong Kong during 2004-2006, including 132 Chinese male nonsmoker cases with lung cancer and 536 nonsmoking community referents (22). They found a weak association between lung cancer and ETS exposure from household/workplace with OR of 1.11, and an increased risk of lung AC with OR of 1.68 .

A recent report by the International Lung Cancer Consortium (ILCCO) in 2014 (24) is valuable in understanding the situation of ETS exposure among never smokers; it includes eight studies in North America, four studies in Europe and six studies in Asia/Oceania. The data comprise 12,688 lung cancer cases and 14,452 controls of which 2,504 cases and 7,276 controls were never smokers. This study showed that exposure to ETS increased risk of lung cancer among both ever smokers and never smokers. The association between ETS exposure and lung cancer development among never smokers was follows: $\mathrm{OR}=1.35$ in males, $\mathrm{OR}=1.27$ in females; $\mathrm{OR}=1.56$ in those $\geq 65$ years old, OR $=1.10$ in those $<65$ years old. The adjusted OR comparing SCLC with NSCLC was 1.28 in the overall population and 2.11 in never smokers.

\section{Clinical Features of Lung AC in Never Smokers}

As noted above, global statistics estimate that $15 \%$ of lung cancer in men and 53\% in women are not attributable to smoking, indicating that worldwide approximately $25 \%$ of 


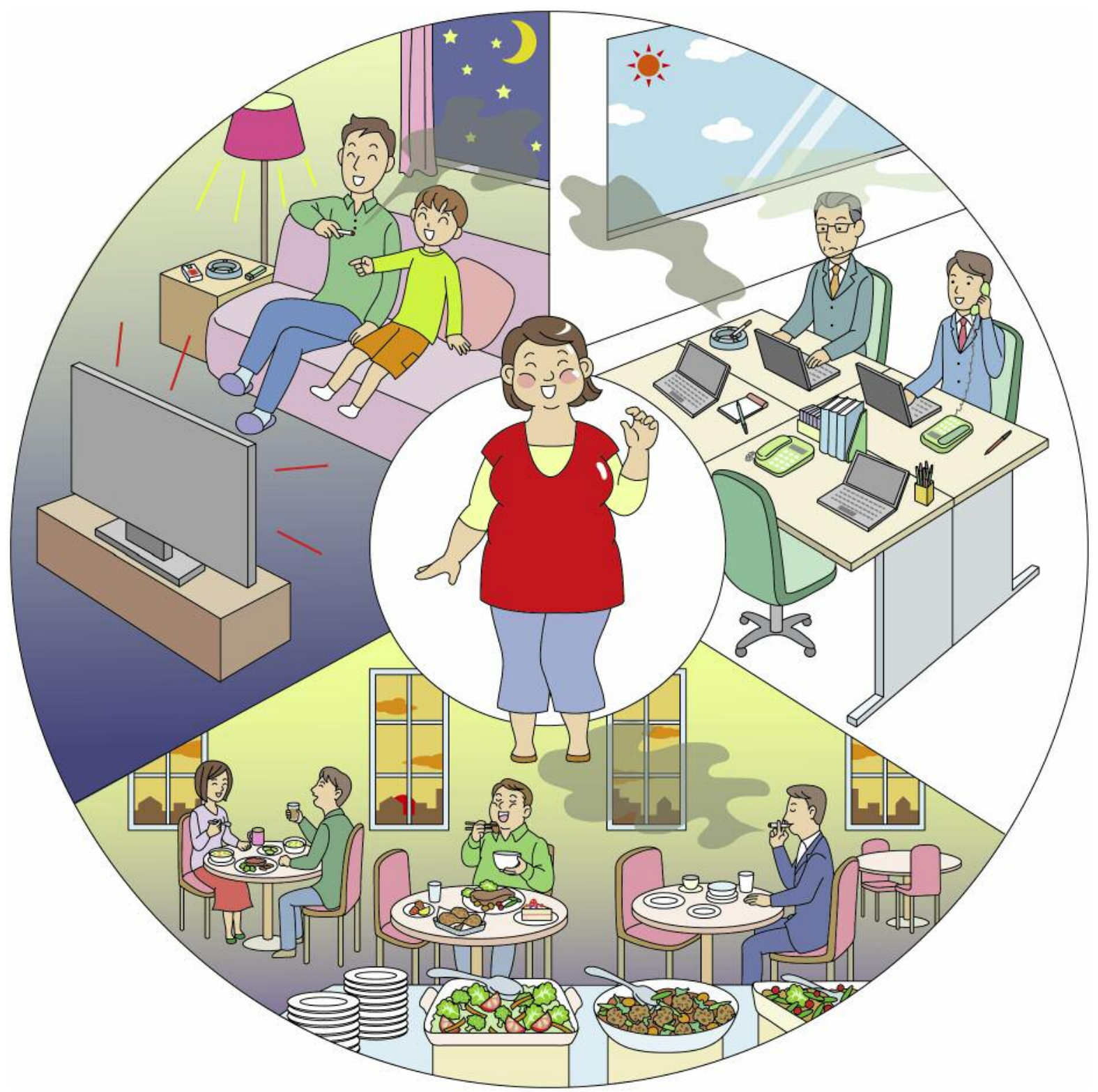

Figure 1. Several scenarios showing sources of exposure to environmental tobacco smoke (ETS). Upper right image shows the possibility of ETS at the workplace. Lower image shows ETS at unidentified places. Upper left shows ETS at the home.

patients with lung cancer are never smokers (5). Moreover, never smoker patients with lung cancer with $\mathrm{AC}$ were female, younger and had a better prognosis $(6,7,10-12)$, although Pallis et al. noted that a correlation between younger age in never smoker lung cancer and the severity of cases was doubtful (9). NSCLC in never smokers is currently on the rise $(16,18,22)$ and there is a question as to whether it may not be a different disease altogether $(23,24)$. Moreover, lung AC harboring an EGFR mutation responds to EGFR-TKIs, while that without EGFR mutation does not $(85,86)$. HER2 amplification was an unfavorable prognostic factor, but HER2 phosphorylation was a favorable prognostic factor (79).

\section{Histopathology of Lung Cancer in Never Smokers}

Incidence of lung $\mathrm{AC}$ in men surpassed the incidence of lung SC in the 1960s and 1970s in the USA and Europe, and in the 1980s and 1990s in Japan (3). The report of the International Association for the Study of Lung Cancer (IASLC) noted imbalance with respect to gender and histology: among 2,341 
Table II. Genes related to susceptibility to metabolic syndrome resembling genes related to susceptibility to lung adenocarcinoma (AC) in never smokers.

\begin{tabular}{|c|c|c|c|}
\hline Gene & Evidence (Ref. no.) & Related signal pathways/comments & Gender \\
\hline VTL1A & $\begin{array}{c}10 \mathrm{q} 25.2(\mathrm{rs} 7086803) \mathrm{OR}=1.32 \\
(5,510 \text { female never smokers/4,510) }(52) .\end{array}$ & $\begin{array}{l}\text { VTL1A is involved in ACRP 30-containing } \\
\text { vesicles in adipocytes. }\end{array}$ & Female \\
\hline $\begin{array}{l}\text { TNFRSF10C } \\
\text { BHLHB5 } \\
\text { BOLL }\end{array}$ & $\begin{array}{l}\text { The methylation of these three genes are } \\
\text { significantly more higher frequency in } \\
\text { patients with lung AC among never } \\
\text { smokers than those in smokers (56). }\end{array}$ & $\begin{array}{l}\text { Lower levels in adipocytes can inhibit adiponectin secretion. } \\
\text { TNFRSF10C is TNF receptor family member. }\end{array}$ & Both \\
\hline C3ORF 21 & rs(952481) OR=0.785 (200/200 Chinese) (39). & $\begin{array}{c}\text { C3ORF21 encodes a UDP-xylose: } \alpha \text {-xylosided, } \\
\text { 3-xylosyl-transferase, which plays an important role } \\
\text { in the formation of notch epidermal growth } \\
\text { factor (NOTCH EGF) repeats. }\end{array}$ & Both \\
\hline$E G F R$ & $\begin{array}{c}\text { EGFR mutation in females } \\
\text { (females } 47.5 \% \text { vs. males } 15.0 \%) \\
\text { (208 Chinese patients with NSCLC) (58). }\end{array}$ & $\begin{array}{c}E G F R \text { mutation and estrogen receptor (ER) } \\
\alpha \text { and } \beta \text {, crosstalk between membranous ER } \alpha \text { and } \\
\text { EGFR mutation has been reported in lung carcinogenesis. }\end{array}$ & Female \\
\hline
\end{tabular}

BHLHB5, Basic helix-loop-helix transcription factor 5; BOLL, boule-like RNA-binding protein; C3ORF21, Chromosome 3 open reading frame 21; EGFR, epidermal growth factor receptor; EGFR-TKI, EGFR-tyrosine kinase inhibitor; OR, odds ratio; NSCLC non-small cell lung cancer; TNFRSF10C, tumor necrosis factor receptor superfamily member 10C; VTL1A, vesicle transport like protein 1A.

female patients, $55 \%$ had AC, $25 \%$ SC, while among 6,796 male patients, 30\% had AC and 57\% SC (1990 2000) (87).

Yang et al. showed a strong association between cigarette smoking history and lung AC in a prospective cohort of 41,836 Iowa women aged 55-69 years with 13 years of follow-up (84). Two-thirds of the enrolled population were never smokers; lung $\mathrm{AC}$ was seen in $25 \%$, SC in $8 \%$ and SCLC in $4 \%$ of all lung cancer. Moreover, they found that women who developed SC consumed more alcohol but less fruit than women with other cancer types, and women who developed SCLC had higher waist circumferences than women with other types of cancer. Women who developed lung cancer were compared with smoker cancer cases, and the differential factors seen in never-smoker cases were higher education, consumption of more fruit, less alcohol and less physical activity.

Seki et al. reported the effects of ETS of spouses on lung cancer in 1,670 cases and 5,855 controls and noted a marginal association of ETS with female lung cancer risk $(\mathrm{OR}=1.31)$, whereas no significant association was observed for lung cancer in men (23). Moreover, a recent report by ILCCO noted that ETS exposure in never smokers or former and current smokers showed a strong association with SCLC (24).

\section{Possibility of Metabolic Syndrome Participating in Lung AC in Never Smokers}

Yang et al. surveyed body mass index (BMI) and waist circumferences in a prospective cohort of 41,836 Iowa women aged 55-69 years with 13 years of follow-up as described above (84). They showed patients with lung cancer had significantly higher waist circumference $(p<0.15)$.
Zhang et al. reported that a comprehensive analysis of adiponectin quantitative trait loci (QTLs) associated with gene expression correlation identified genes related to metabolic syndrome with a potential role in carcinogenesis (88). As discussed above, genes related to susceptibility to lung $\mathrm{AC}$ in never smokers include classical genes (participating in detoxifying or metabolizing carcinogenic agents derived mainly from tobacco smoke, tumorsuppressor genes such as TP53 and TP63, and DNA damagerepair genes), genes found by GWAS (nicotine acetylcholine esterase genes, TERT and CLPTM1L, VTL1A, GPC5, TNFRSF10C, C3ORF21, hypermethylation of TNFSF10C, $B H L H B 5$, and $B O L L$ ), and driver genes (EGFR, KRAS, BRAF, PIK3CA, EML4-ALK) have been reported (17). Although these genes are not related to metabolic syndrome, EGFR, VTL1A, TNFRSF10C, C3ORF21 and hypermethylation of TNFSF10C, BHLHB5, and BOLL are involved in the metabolic pathways of metabolic syndrome (Table II). Mazieres et al. reported a close relationship between lung AC in never smokers and metabolic syndrome (89). They examined 140 women with AC (63 never smokers and 77 former/current smokers) and found that never smokers were characterized by a higher frequency of lipidic features $(60.3 \%$ vs. $37.7 \%)$ compared with smokers (89). Obesity, lack of physical activity, heavy alcohol consumption and a diet of food with high fat content all lead to metabolic syndrome and a high percentage of cancer $(90,91)$. Metabolic syndrome is frequently complicated with type-2 diabetes mellitus, which is associated with increased risk of lung cancer, especially among female diabetic patients with $\mathrm{RR}=1.14$ (92). 


\section{Predominance of Women Among Never Smokers}

Among the never-smoker patients with lung AC, there were fewer female patients than male patients. However, the percentage of never smokers among total females with lung $\mathrm{AC}$ was over $50 \%$. It has been reported that these female patients were younger and had better prognoses, as mentioned above (6-12).

It remains unknown why lung $\mathrm{AC}$ is seen in Asian women never smokers $(4,16)$. Association of EGFR mutation and estrogen receptor (ER)- $\alpha$ and $-\beta$ with lung carcinogenesis has been reported $(93,94)$. Mazieres et al. observed increased frequency of EGFR mutation and ER $\alpha$ expression in never smokers with $\mathrm{AC}$ with higher frequency of lipidic features (89). Li et al. also revealed that EGFR mutations were seen in $24.5 \%$ (51/208 cases) of patients with lung cancer. These mutations were identified with higher frequency in females $(47.5 \%$ vs. $15.0 \%$ in males), never smokers ( $42.3 \%$ vs. $13.9 \%$ in smokers), and patients with AC (44.2\% vs. $8.0 \%$ in patients with non-AC) (58). Moreover, human papillomavirus (HPV) infection may be involved in Asian non-smoking lung AC, which responds to EGFR-TKIs (95). Women with early menarche or late menopause showed significantly increased risk of lung cancer (96). Further epidemiological research should be conducted to clarify these points.

\section{Interaction of Susceptibility Genes and Suspected Carcinogens}

There is much information on genes related to susceptibility to lung AC in never smokers as detailed above. Comparing original articles of the 1990s with those published after 2000 by meta-analysis, Okazaki et al. reported that the role of classical genes associated with lung cancer is decreasing and novel genes are emerging (2010), a fact that may reflect changes in lifestyle in Japan (3). Although the carcinogenesis of lung AC in smokers is simple, that in never smokers is complicated. However, clarification is necessary for primary prevention of lung AC. Moreover, the numbers of patients with lung AC in never smokers is increasing for both sexes. Generally the frequency among female never smokers was predominant in lung AC. In developed countries, even though the frequency in men is less than in women, that in never smoker male patients increases after quitting smoking (4).

Different genes associated with susceptibility to cancer of course relate to different metabolic pathways to lung AC. For example, never smokers exposed to ETS exhibited the changes related to classical genes as Bennett et al. suggested (34). Members of the same group, Olivo-Marston et al. showed that ETS exposure during childhood might result in more susceptibility to ETS in never smokers with a haplotype of $M B L 2$, suggesting alteration in inherited genetic
Table III. Suspected carcinogens and genes involved in susceptibility to lung AC reported among never smokers.

\begin{tabular}{|c|c|}
\hline Suspected carcinogen & Gene \\
\hline Environmental tobacco smoke & $\begin{array}{l}\text { 1. Classical genes } \\
\text { CYP1B1 Leu432 Val/CYP!A1 } \\
\text { Ile } 462 \text { Val }(33,36), \\
\text { GSTM1 null }(34,35,36), \\
\text { NQO1 T allele (41), AGT gene (42) } \\
\text { 2. GWAS } \\
\text { GPC5 (54) } \\
\text { 3. Driver genes } \\
\text { EGFR mutation (60) } \\
\text { 4. Immunity-related } \\
\text { MBL2 haplotype (67) }\end{array}$ \\
\hline Radon & $\begin{array}{l}\text { 1. Classical genes } \\
\text { GSTM1 and GSTT1 gene } \\
\text { deletion }(29)^{*} \\
\text { TP53 }(29)^{*} \\
\text { DNA-repair gene } \\
\text { polymorphisms }(29)^{*}\end{array}$ \\
\hline Indoor cooking oil fumes & $\begin{array}{l}\text { 1. Classical genes } \\
\text { NAT2 (37), } \\
\text { ATMrs189037 AA genotype (40), }\end{array}$ \\
\hline Indoor wood combustion & $\begin{array}{l}\text { 1. Classical genes } \\
\text { GSTM1 and GSTT1 gene } \\
\text { deletion (36) }\end{array}$ \\
\hline Hormone replacement therapy & $?$ \\
\hline Infection & Oncogenic virus? \\
\hline
\end{tabular}

GWAS, Genome-wide association study. *Choi et al. (29) reviewed genes susceptible to radon (includes 28 genes).

variants of innate immunity genes (67). Li et al. found glypican-5 to be a novel gene related to susceptibility to lung $\mathrm{AC}$ in never smokers, and showed the possibility of a role for ETS in carcinogenesis in never smokers (54). Although the role of carcinogens in never smokers with most defined genes related to susceptibility remains unknown, the reported interrelations are shown in Table III.

Lee et al. clearly demonstrated that $E G F R$ mutation rate was $56.6 \%$ in lung cancer in never smokers without ETS exposure, $44.0 \%$ in lung cancer in never smokers exposed for $<45$ ETS smoker years and $25.7 \%$ in lung cancer in never smokers exposed for $\geq 45$ ETS smoker years (60). The same trend was seen for childhood ETS exposure, and household $v s$. workplace ETS, i.e. EGFR mutation rate was higher in never smokers without ETS, but a high level of ETS was associated with a low EGFR mutation rate; the EGFR mutation rate was lowest in smokers with lung cancer. According to the review of Choi et al., radon is recognized as the second leading carcinogen of lung cancer, and they listed the genes related to susceptibility as shown in Table III (29).

Subramanian and Govindan reviewed pre-existing lung diseases, oncogenic viruses and human papillomavirus in carcinogenesis of lung cancer in never smokers (97), and 
they also referred to Schabath et al.'s study (98), in which estrogen replacement therapy was used to exert a protective effect on women against developing lung cancer. Hormone or hormone replacement therapy should be investigated from the viewpoint of carcinogenesis between carcinogen and susceptible genes; further research is necessary.

We reported the possibility of genes associated with metabolic syndrome being related to lung AC in never smokers (17). However, while ETS and the other agents shown in Table III are suspected carcinogens, it is not yet clear whether they actually are. The references shown in Table II did not reveal the physical characteristics of metabolic syndrome such as body weight, body length, BMI, waist circumferences, hypertension, hyperlipidemia, blood sugar levels and hemoglobin A1c (HbA1c) levels (99). Even if the study subjects of these reports had the physical characteristics of metabolic syndrome, ETS or other carcinogens, drugs, infectious agents might be responsible for causing lung cancer because metabolic syndrome, obesity and type 2 diabetes mellitus are known to be complicating factors in malignant disease. The carcinogen(s) involved in never-smoker patients with lung cancer and metabolic syndrome requires further elucidation.

\section{Future Directions}

For primary prevention of lung AC in never smokers, of course, it is necessary to educate the general population that they should quit smoking and reduce ETS. We should promote the conduct of epidemiological surveys of suspected carcinogens in individual districts in order to clarify the carcinogenesis of lung AC in each case with genes related to susceptibility to cancer.

The relationship between AC and metabolic syndrome is especially important, because in general Asians are increasingly suffering from increased obesity and type- 2 diabetes mellitus (92) as their life-styles change to include more Western-type foods and they engage in less physical activity. A recent report by Zanetti et al. showed the importance of ethnic groups with respect to susceptibility genes (100). The interaction of these genes and carcinogens, even if they are only suspected, should be investigated. The well-known review by Sun et al. (6) pointed out that $E G F R$ mutation in never smokers $v s$. KRAS mutation and TP53 mutation in never smokers are frequently seen, and these differences in never smokers support the idea that different carcinogens are involved for different groups of never smokers. Moreover, the study of different oncogenic mutation spectra of lung AC in never smokers can lead to better selection of effective treatments and improve prognosis. We could establish strategies for primary prevention of lung $\mathrm{AC}$ in never smokers if we start to conduct surveys in individual districts.

\section{Conflicts of Interest}

The Authors confirm that there are no conflicts of interest regarding the contents of this article. This study was approved by the Ethics Committee of the International University of Health and Welfare (13-B-130; October 10, 2015).

\section{Acknowledgements}

The Authors thank Ms. Yoshie Muroya for her systematic research of the literature and Ms. Cecilia Hamagami for her assistance in the English revision of the manuscript.

The Authors are grateful to the Smoking Research Foundation (Tokyo, Japan) for support of this research in 2015 2016 (IO. SI, YS).

\section{References}

1 Torre LA, Bray F, Siegel RL, Ferlay J, Lortet-Tieulent J and Jemal A: Global cancer statistics, 2012. CA Cancer J Clin 65: 87-108, 2015.

2 Devesa SS, Bray F, Vizcaino AP and Parkin DM: International lung cancer trends by histological type: male:female differences diminishing and adenocarcinoma rising. Int J Cancer 117: 294299, 2005.

3 Okazaki I, Sugita M, Matsuki H, Billah SM and Watanabe T: Additional candidates to conventional genes susceptible for lung cancer and changing trend in Japan (Review). Oncol Rep 23: 1493-1500, 2010.

4 Islami F, Torre LA and Jemal A: Global trends of lung cancer mortality and smoking prevalence. Transl Lung Cancer Res 4: 327-338, 2015.

5 Parkin DM, Bray F, Ferley $\mathrm{J}$ and Pisani P: Global cancer statistics, 2002. CA Cancer J Clin 55: 74-108, 2005.

6 Sun S. Shiller JH and Gazdar AF: Lung cancer in never smokers - a different disease. Nat Rev Cancer 7: 778-790, 2007.

7 Kawaguchi T, Takada M, Kubo A, Matsumura A, Fukai S, Tamura A, Saito R, Kawahara M and Maruyama Y: Gender, histology, and time of diagnosis are important factors for prognosis. Analysis of 1499 never-smokers with advanced nonsmall cell lung cancer in Japan. J Thorac Oncol 5: 1011-1017, 2010.

8 Couraud S, Zalcman G, Milleron B, Morin F and Souquet PJ: Lung Cancer in never smokers - A review. Eur J Cancer 48: 1299-1311, 2012.

9 Pallis AG and Syrigos KN: Lung cancer in never smokers: Disease characteristics and risk factors. Clin Rev Oncol Hematol 88: 494-503, 2013.

10 Santro IL, Ramos RP, Franceschini J, Jamnik S and Fernandes AL: Non-small cell lung cancer in never smokers: a clinical entity to be identified. Clinics 66: 1873-1877, 2011.

11 Sasaki T, Rodig SJ, Chirieac LR and Jänne PA: The biology and treatment of EML4-ALK non-small cell lung cancer. Eur J Cancer 46: 1773-1780, 2010.

12 Lee DH, Lee JS, Wang J, Hsia TC, Wang X, Kim J and Orlando $\mathrm{M}$ : Pemetrexed-erlotinib, pemetrexed alone, erlotinib alone as second-line treatment for East Asia and non-East Asia never smokers with locally advanced or metastatic nonsquamous nonsmall cell lung cancer exploratory subgroup analysis of a phase II trial. Cancer Res Treat 47: 616-629, 2015. 
13 Miller VA, Kris MG, Shah N, Patel J, Azzoli C, Gomez J, Krug LM, Pao W, Rizvi N, Pizzo B, Tyson L, Venkatraman E, BenPorat L, Memoli N, Zakowski M, Rusch V and Heelan RT: Bronchioloalveolar pathologic subtype and smoking history predict sensitivity to gefitinib in advanced non-small-cell lung cancer. J Clin Oncol 22: 1103-1109, 2004.

14 Shigematsu H, Lin L, Takahashi T, Nomura M, Suzuki M, Wistuba II, Fong KM, Lee H, Toyooka S, Shimizu N, Fujisawa T, Feng Z, Roth JA, Herz J, Minna JD and Gazdar AF: Clinical and biological features associated with epidermal growth factor receptor gene mutations in lung cancers. J Natl Cancer Inst 97: 339-346, 2005.

15 Yano T. Haro A, Shikada Y, Maruyama R and Maehara Y: Nonsmall cell lung cancer in never smokers as a representative 'nonsmoking-associated lung cancer': epidemiology and clinical features. Int J Clin Oncol 16: 287-293, 2011.

16 Badar F. Meerza F, Khokhar RA, Ali FA, Irfan N, Kamran S, Shahid $\mathrm{N}$ and Mahmood S: Characteristics of lung cancer patients - the Shaukat Khanum Memorial experience. Asian Pac J Cancer Prev 7: 245-248, 2006.

17 Okazaki I, Ishikawa S and Sohara Y: Genes associated with susceptibility to lung adenocarcinoma among never smokers suggest the mechanism of disease. Anticancer Res 34: 52295240, 2014.

18 Bae J-M: Modifiable risk factors of lung cancer in "neversmoker" women. Epidemiol Health 37: e2015047. 2015.

19 Boffetta P: Involuntary smoking and lung cancer. Scand J Work Environ Health 28(Suppl 2): 30-40, 2002.

20 Wenzlaff AS, Cote ML, Bock CH, Land SJ and Schwartz AG: GSTM1, GSTT1 and GSTP1 polymorphisms, environmental tobacco smoke exposure and risk of lung cancer among never smokers: a population-based study. Carcinogenesis 26: 395-401, 2005.

21 Kurahashi N, Inoue M, Liu Y, Iwasaki M, Sasazuki S, Sobue T, Tsugane S and JPHC Study Group: Passive smoking and lung cancer in Japanese non-smoking women: A prospective study. Int J Cancer 122: 653-657, 2008.

22 Tse LA, Yu IT, Au JS, Yu KS, Kwok KP, Qiu H and Wong TW: Environmental tobacco smoke and lung cancer among Chinese nonsmoking males: Might adenocarcinoma be the culprit? Am J Epidemiol 169: 533-541, 2009.

23 Seki T, Nishino Y, Tanji F, Maemondo M, Takahashi S, Sato I, Kawai $\mathrm{M}$ and Minami Y: Cigarette smoking and lung cancer risk according to histologic type in Japanese men and women. Cancer Sci 104: 1515-1522, 2013.

24 Kim CH, Lee YC, Hung RJ, McNallan SR, Cote ML, Lim WY, Chang SC, Kim JH, Ugolini D, Chen Y, Liloglou T, Andrew AS, Onega T, Duell EJ, Field JK, Lazarus P, Le Marchand L, Neri M, Vineis P, Kiyohara C, Hong YC, Morgenstern H, Matsuo K, Tajima K, Christiani DC, McLaughlin JR, Bencko V, Holcatova I, Boffetta P, Brennan P, Fabianova E, Foretova L, Janout V, Lissowska J, Mates D, Rudnai P, Szeszenia-Dabrowska N, Mukeria A, Zaridze D, Seow A, Schwartz AG, Yang P and Zhang ZF: Exposure to secondhand tobacco smoke and lung cancer by histological type: a pooled analysis of the International Lung Cancer Consortium (ILCCO). Int J Cancer 135: 1918-1930, 2014.

25 Adair-Kirk TL, Atkinson JJ and Senior RM: Smoke particulates stress lung cells. Nature Med 14: 1024-1025, 2008.

26 Stocks T, Van Hemelrijck M, Manjer J, Bjørge T, Ulmer H, Hallmans G, Lindkvist B, Selmer R, Nagel G, Tretli S, Concin $\mathrm{H}$, Engeland A, Jonsson $\mathrm{H}$ and Stattin P: Blood pressure and risk of cancer incidence and mortality in the metabolic syndrome and cancer project. Hypertension 59: 802-810, 2012.

27 Choi $\mathrm{H}$ and Mazzone P: Radon and lung cancer: assessing and mitigating the risk. Clev Clin J Med 81: 567-575, 2014.

28 Lino Ada R, Abrahão CM, Amarante MP and de Sousa Cruz MR: The role of the implementation of policies for the prevention of exposure to radon in Brazil - a strategy for controlling the risk of developing lung cancer. ECancer 9: 572, 2015.

29 Choi JR, Park SY, Noh OK, Koh YW and Kang DR: Gene mutation discovery research of non-smoking lung cancer patients due to indoor radon exposure. Ann Occupation Environ Med 28: $13,2016$.

30 Secretan B, Straif K, Baan R, Grosse Y, El Ghissassi F, Bouvard V, Benbrahim-Tallaa L, Guha N, Freeman C, Galichet L, Cogliano V and WHO International Agency for Research on Cancer Monograph Working Group: A review of human carcinogens - Part E: tobacco, areca nut, alcohol, coal smoke, and salted fish. Lancet Oncol 10: 1033-1034, 2009.

31 Cheng YW, Chiou HL, Sheu GT, Hsieh LL, Chen JT, Chen CY, Su JM and Lee H: The association of human papillomavirus 16/18 infection with lung cancer among nonsmoking Taiwanese women. Cancer Res 61: 2799-2803, 2001.

32 Liang HY, Li XL, Yu XS, Guan P, Yin ZH, He QC and Zhou BS: Facts and fiction of the relationship between preexisting tuberculosis and lung cancer risk: a systematic review. Intl J Cancer 125: 2936-2944, 2009.

33 Yoon KA, Kim JH, Gil H-J, Hwang H, Hwangbo B and Lee JS: $C Y P 1 B 1, C Y P 1 A 1, M P O$, and GSTP1 polymorphisms and lung cancer risk in never-smoking Korean women. Lung Cancer 60 : 40-46, 2008.

34 Bennett WP, Alavanja MC, Blomeke B, Vähäkangas $\mathrm{KH}$, Castrén K, Welsh JA, Bowman ED, Khan MA, Flieder DB and Harris CC: Environmental tobacco smoke, genetic susceptibility, and risk of lung cancer in never-smoking women. J Natl Cancer Inst 91: 2009-2014, 1999.

35 Hung RJ, Boffetta P, Brockmöller J, Butkiewicz D, Cascorbi I, Clapper ML, Garte S, Haugen A, Hirvonen A, Anttila S, Kalina I, Le Marchand L, London SJ, Rannug A, Romkes M, Salagovic J, Schoket B, Gaspari L and Taioli E: CYP1A1 and GSTM1 genetic polymorphisms and lung cancer risk in Caucasian nonsmokers: a pooled analysis. Carcinogenesis 24: 875-882, 2003.

36 Malats N, Camus-Radon A-M, Nyberg F, Ahrens W, Constantinescu V Mukeria A, Benhamou S, Batura-Gabryel H, Bruske-Hohlfeld I, Simonato L, Menezes A, Lea S, Lang M and Boffetta P: Lung cancer risk in nonsmokers and GSTM1 and GSTT1 genetic polymorphism. Cancer Epidemiol Biomark Prev 9: 827-833, 2000.

37 Chiou HL, Wu MF, Chien WP, Cheng YW, Wong RH, Chen CY, Lin TS and Lee H: NAT2 fast acetylator genotype is associated with an increased risk of lung cancer among never-smoking women in Taiwan. Cancer Lett 223: 93-101, 2005.

38 Hosgood HD 3rd, Wang WC, Hong YC, Wang JC, Chen K, Chang IS, Chen CJ, Lu D, Yin Z, Wu C, Zheng W, Qian B, Park JY, Kim YH, Chatterjee N, Chen Y, Chang GC, Hsiao CF, Yeager M, Tsai YH, Wei H, Kim YT, Wu W, Zhao Z, Chow WH, Zhu X, Lo YL, Sung SW, Chen KY, Yuenger J, Kim JH, Huang L, Chen YH, Gao YT, Kim JH, Huang MS, Jung TH, Caporaso N, Zhao X, Huan Z, Yu D, Kim CH, Su WC, Shu XO, Kim IS, Bassig B, Chen YM, Cha SI, Tan W, Chen H, Yang TY, Sung JS, Wang CL, Li X, Park KH, Yu CJ, Ryu JS, Xiang Y, 
Hutchinson A, Kim JS, Cai Q, Landi MT, Lee KM, Hung JY, Park JY, Tucker M, Lin CC, Ren Y, Perng RP, Chen CY, Jin L, Chen KC, Li YJ, Chiu YF, Tsai FY, Yang PC, Fraumeni JF Jr., Seow A, Lin D, Zhou B, Chanock S, Hsiung CA, Rothman N and Lan Q: Genetic variant in TP63 on locus $3 \mathrm{q} 28$ is associated with risk of lung adenocarcinoma among never-smoking females in Asia. Hum Genet 131: 1197-1203, 2012.

39 Zhang Y, Gu C, Shi H, Zhang A, Kong X, Bao W, Deng D, Ren $\mathrm{L}$ and $\mathrm{Gu} \mathrm{D}$ : Association between C3ORF21, TP63 polymorphisms and environment and NSCLC in never-smoking Chinese population. Gene 49: 93-97, 2012.

40 Shen L, Zhiha Y, Wu W, Ren Y, Li X and Zhou B: Single nucleotide polymorphism in ATM gene, cooking oil fumes and lung adenocarcinoma susceptibility in Chinese female nonsmokers: A case-control study. PLOS ONE 9: e96911(1-7), 2014

41 Bock CH, Wenzlaff AS, Cote ML, Land SJ and Schwartz AG: NQO1 T allele associated with decreased risk of later age at diagnosis lung cancer among never smokers: results from a population-based study. Carcinogenesis 2: 381-386, 2005.

42 Cohet C, Borel S, Nyberg F, Mukeria A, Brüske-Hohlfeld I, Constantinescu V, Benhamou S, Brennan P, Hall J and Boffetta P: Exon 5 polymorphisms in the $O^{6}$-alkylguanine DNA alkyltransferase gene and lung cancer risk in non-smokers exposed to second-hand smoke. Cancer Epidemiol Biomarkers Prev 13: 320-323, 2004.

43 Pulling LC, Divine KK, Klinge DM, Gilliland FD, Kang T, Schwartz AG, Bocklage TJ and Belinsky SA: Promoter hypermethylation of the $O^{6}$-methylguanine-DNA methyltransferase gene: More common in lung adenocarcinomas from never-smokers than smokers and associated with tumor progression. Cancer Res 63: 4842-4848, 2003.

44 Wu C, Hu Z, Yu D, Huang L, Jin G, Liang J, Guo H, Tan W, Zhang M, Qian J, Lu D, Wu T, Lin D and Shen H: Genetic variants on chromosome $15 \mathrm{q} 25$ associated with lung cancer risk in Chinese populations. Cancer Res 69: 5065-5072, 2009.

45 Shiraishi K, Kohno T, Kunitoh H, Watanabe S, Goto K, Nishiwaki Y, Shimada Y, Hirose H, Saito I, Kuchiba A, Yamamoto S and Yokota J: Contribution of nicotine acetylcholine receptor polymorphisms to lung cancer risk in a smoking-independent manner in the Japanese. Carcinogenesis 30: 65-70, 2009.

46 Pande M, Spitz MR, Wu X, Gorlov IP, Chen WV and Amos CI: Novel genetic variants in the chromosome $5 \mathrm{p} 15.33$ region associate with lung cancer risk. Carcinogenesis 32: 1493-1499, 2011.

47 Wang Y, Broderick P, Matakidou A, Eisen T and Houlston RS: Role of 5p15.33 (TERT-CLPTM1L), 6p21.33 and 15q25.1 (CHRNA5-CHRNA3) variation and lung cancer risk in neversmokers. Carcinogenesis 31: 234-238, 2010.

48 Hsiung CA, Lan Q, Hong YC, Chen CJ, Hosgood HD, Chang IS, Chatterjee N, Brennan P, Wu C, Zheng W, Chang GC, Wu T, Park JY, Hsiao CF, Kim YH, Shen H, Seow A, Yeager M, Tsai YH, Kim YT, Chow WH, Guo H, Wang WC, Sung SW, Hu Z, Chen KY, Kim JH, Chen Y, Huang L, Lee KM, Lo YL, Gao YT, Kim JH, Liu L, Huang MS, Jung TH, Jin G, Caporaso N, Yu D, Kim CH, Su WC, Shu XO, Xu P, Kim IS, Chen YM, Ma H, Shen M, Cha SI, Tan W, Chang CH, Sung JS, Zhang M, Yang TY, Park KH, Yuenger J, Wang CL, Ryu JS, Xiang Y, Deng Q, Hutchinson A, Kim JS, Cai Q, Landi MT, Yu CJ, Park JY, Tucker M, Hung JY, Lin CC, Perng RP, Boffetta P, Chen CY, Chen KC, Yang SY, Hu CY, Chang CK, Fraumeni JF Jr, Chanock S, Yang PC, Rothman N and Lin D: The 5p15.33 locus is associated with risk of lung adenocarcinoma in never-smoking females in Asia. PLos Genet 6: e1001051, 2010.

49 Landi MT, Chatterjee N, Yu K, Goldin LR, Goldstein AM, Rotunno M, Mirabello L, Jacobs K, Wheeler W, Yeager M, Bergen AW, Li Q, Consonni D, Pesatori AC, Wacholder S, Thun M, Diver R, Oken M, Virtamo J, Albanes D, Wang Z, Burdette L, Doheny KF, Pugh EW, Laurie C, Brennan P, Hung R, Gaborieau V, McKay JD, Lathrop M, McLaughlin J, Wang Y, Tsao MS, Spitz MR, Wang Y, Krokan H, Vatten L, Skorpen F, Arnesen E, Benhamou S, Bouchard C, Metspalu A, Vooder T, Nelis M, Välk K, Field JK, Chen C, Goodman G, Sulem P, Thorleifsson G, Rafnar T, Eisen T, Sauter W, Rosenberger A, Bickeböller H, Risch A, Chang-Claude J, Wichmann HE, Stefansson K, Houlston R, Amos CI, Fraumeni JF Jr., Savage SA, Bertazzi PA, Tucker MA, Chanock S and Caporaso NE: A genome-wide association study of lung cancer identifies a region of chromosome $5 \mathrm{p} 15$ associated with risk for adenocarcinoma. Am J Hum Genet 85: 679-691, 2009.

50 Jin G, Xu L, Shu Y, Tian T, Liang J, Xu Y, Wang F, Chen J, Dai $\mathrm{J}, \mathrm{Hu} \mathrm{Z}$ and Shen $\mathrm{H}$ : Common genetic variants on $5 \mathrm{p} 15.33$ contribute to risk of lung adenocarcinoma in a Chinese population. Carcinogenesis 30: 987-990, 2009.

51 McKay JD, Hung RJ, Gaborieau V, Boffetta P, Chabrier A, Byrnes G, Zaridze D, Mukeria A, Szeszenia-Dabrowska N, Lissowska J, Rudnai P, Fabianova E, Mates D, Bencko V, Foretova L, Janout V, McLaughlin J, Shepherd F, Montpetit A, Narod S, Krokan HE, Skorpen F, Elvestad MB, Vatten L, Njølstad I, Axelsson T, Chen C, Goodman G, Barnett M, Loomis MM, Lubiñski J, Matyjasik J, Lener M, Oszutowska D, Field J, Liloglou T, Xinarianos G, Cassidy A; EPIC Study, Vineis P, Clavel-Chapelon F, Palli D, Tumino R, Krogh V, Panico S, González CA, Ramón Quirós J, Martínez C, Navarro C, Ardanaz E, Larrañaga N, Kham KT, Key T, Bueno-de-Mesquita HB, Peeters PH, Trichopoulou A, Linseisen J, Boeing H, Hallmans G, Overvad K, Tjønneland A, Kumle M, Riboli E, Zelenika D, Boland A, Delepine M, Foglio M, Lechner D, Matsuda F, Blanche H, Gut I, Heath S, Lathrop M and Brennan P: Lung cancer susceptibility locus at $5 \mathrm{p} 15.33$. Nat Genet 40 : 1404-1406, 2008.

52 Lan Q, Hsiung CA, Matsuo K, Hong YC, Seow A, Wang Z, Hosgood HD 3rd, Chen K, Wang JC, Chatterjee N, Hu W, Wong MP, Zheng W, Caporaso N, Park JY, Chen CJ, Kim YH, Kim YT, Landi MT, Shen H, Lawrence C, Burdett L, Yeager M, Yuenger J, Jacobs KB, Chang IS, Mitsudomi T, Kim HN, Chang GC, Bassig BA, Tucker M, Wei F, Yin Z, Wu C, An SJ, Qian B, Lee VH, Lu D, Liu J, Jeon HS, Hsiao CF, Sung JS, Kim JH, Gao YT, Tsai YH, Jung YJ, Guo H, Hu Z, Hutchinson A, Wang WC, Klein R, Chung CC, Oh IJ, Chen KY, Berndt SI, He X, Wu W, Chang J, Zhang XC, Huang MS, Zheng H, Wang J, Zhao X, Li Y, Choi JE, Su WC, Park KH, Sung SW, Shu XO, Chen YM, Liu L, Kang $\mathrm{CH}, \mathrm{Hu} \mathrm{L}$, Chen CH, Pao W, Kim YC, Yang TY, Xu J, Guan P, Tan W, Su J, Wang CL, Li H, Sihoe AD, Zhao Z, Chen Y, Choi YY, Hung JY, Kim JS, Yoon HI, Cai Q, Lin CC, Park IK, Xu P, Dong J, Kim C, He Q, Perng RP, Kohno T, Kweon SS, Chen CY, Vermeulen R, Wu J, Lim WY, Chen KC, Chow WH, Ji BT, Chan JK, Chu M, Li YJ, Yokota J, Li J, Chen H, Xiang YB, Yu CJ, Kunitoh H, Wu G, Jin L, Lo YL, Shiraishi K, Chen YH, Lin HC, Wu T, Wu YL, Yang PC, Zhou B, Shin MH, Fraumeni JF Jr., Lin $\mathrm{D}$, Chanock SJ and Rothman N: Genome-wide association analysis identifies new lung cancer susceptibility loci in neversmoking women in Asia. Nat Genet 44: 1330-1335, 2012. 
53 Ahn MJ, Won HH, Lee J, Lee ST, Sun JM, Park YH, Ahn JS, Kwon OJ, Kim H, Shim YM, Kim J, Kim K, Kim YH, Park JY, Kim JW and Park K: The 18p11.22 locus is associated with never smoker non-small cell lung cancer susceptibility in Korean populations. Hum. Genet 131: 365-372, 2012.

54 Li Y, Sheu CC, Ye Y, de Andrade M, Wang L, Chang SC, Aubry MC, Aakre JA, Allen MS, Chen F, Cunningham JM, Deschamps C, Jiang R, Lin J, Marks RS, Pankratz VS, Su L, Li Y, Sun Z, Tang H, Vasmatzis G, Harris CC, Spitz MR, Jen J, Wang R, Zhang ZF, Christiani DC, Wu X and Yang P: Genetic variants and risk of lung cancer in never smokers: a genome-wide association study. Lancet Oncol 11: 321-330, 2010.

55 Landi MT, Chatterjee N, Caporaso NE, Rotunno M, Albanes D, Thun M, Wheeler W, Rosenberger A, Bickeböller H, Risch A, Wang Y, Gaborieau V, Thorgeirsson T, Gudbjartsson D, Sulem P, Spitz MR, Wichmann HE, Rafnar T, Stefansson K, Houlston RS and Brennan P: GPC5 rs2352028 variant and risk of lung cancer in never smokers. Lancet Oncol 11: 714-716, 2010.

56 Tessema M, Yu YY, Stidley CA, Machida EO, Schuebel KE, Baylin SB and Belinsky SA: Concomitant promoter methylation of multiple genes in lung adenocarcinomas from current, former and never smokers. Carcinogenesis 30: 11321138,2009

57 An S-J, Chen ZH, Su J, Zhang XC, Zhong WZ, Yang JJ, Zhou Q, Yang XN, Huang L, Guan JL, Nie Q, Yan HH, Mok TS and $\mathrm{Wu}$ YL: Identification of enriched driver gene alterations in subgroups of non-small cell lung cancer patients based on histology and smoking status. PLoS One 7: e40109, 2012.

58 Li Y, Li Y, Yang T, Wei S, Wang J, Wang M, Wang Y, Zhou Q, Liu $\mathrm{H}$ and Chen J: Clinical significance of EML4-ALK fusion gene and association with EGFR and KRAS gene mutations in 208 Chinese patients with non-small cell lung cancer. PLoS One 8: e52093 (1-12), 2013.

59 Ren S, Kuang P, Zheng L, Su C, Li J, Li B, Chen X, Wang Y, KimCurran V, Liu L, Hu Q, Zhang J, Tang L and Zhou C: Analysis of driver mutations in female non-smoker Asian patients with pulmonary adenocarcinoma. Cell Biochem Biophys 64: 155-160, 2012.

60 Lee YJ, Cho BC, Jee SH, Moon JW, Kim SK, Chang J, Chung $\mathrm{KY}$, Park IK, Choi SH and Kim JH: Impact of environmental tobacco smoke on the incidence of mutations in epidermal growth factor receptor gene in never-smoker patients with nonsmall-cell lung cancer. J Clin Oncol 28: 487-492, 2009.

61 Jou YS, Lo YL, Hsiao CF, Chang GC, Tsai YH, Su WC, Chen YM, Huang MS, Chen HL, Chen CJ, Yang PC and Hsiung CA: Association of an EGFR intron $1 \mathrm{SNP}$ with never-smoking female lung adenocarcinoma patients. Lung Cancer 64: 251-256, 2009.

62 Jo UH, Han SG, Seo JH, Park KH, Lee JW, Lee HJ, Ryu JS and Kim YH: The genetic polymorphisms of HER2 and the risk of lung cancer in a Korean population. BMC Cancer 8: 359 (1-9), 2008.

63 Jang JS, Lee A, Li J, Liyanage H, Yang Y, Guo L, Asmann YW, Li PW, Erickson-Johnson M, Sakai Y, Sun Z, Jeon H-S, Hwang H, Bungum AO, Edell ES, Simon VA, Kopp KJ, Eckloff B, Oliveira AM, Wieben E, Aubry MC, Yi E, Wigle D, Diasio RB, Yang $\mathrm{P}$ and Jen $\mathrm{J}$ : Common oncogene mutations and novel SND1-BRAF transcript fusion in lung adenocarcinoma from never smokers. Scie Rep 5: 9755 (2015)/DOI:10.1038/srep09755
64 Iwamoto S, Tanimoto K, Nishio Y, Putra AC, Fuchita H, Ohe M, Sutani A, Kuraki T, Hiyama K, Murakami I, Eguchi H and Isobe T: Association of EPAS1 gene rs4953354 polymorphism with susceptibility to lung adenocarcinoma in female Japanese nonsmokers. J Thorac Oncol 9: 1709-1713, 2014.

65 Kang H-G, Lee SY, Jeon H-S, Choi YY, Kim S, Lee WK, Lee HC, Choi JE, Bae EY, Yoo SS, Lee J, Cha SI, Kim CH, Lee MH, Kim YT, Kim JH, Hong Y-C, Kim YH and Park JY: A functional polymorphism in $C S F 1 R$ gene is a novel susceptibility marker for lung cancer among never-smoking females. J Thorac Oncol 9: 1647-1655, 2014

66 Kiyohara C, Horiuchi T, Takayama K and Nakanishi Y: IL1B rs1143634 polymorphism, cigarette smoking, alcohol use, and lung cancer risk in a Japanese population. J Thorac Oncol 5: 299-304, 2010

67 Olivo-Marston SE, Yang P, Mechanic LE, Bowman ED, Pine SR, Loffredo CA, Alberg AJ, Caporaso N, Shields PG, Chanock $\mathrm{S}$, Wu $\mathrm{Y}$, Jiang $\mathrm{R}$, Cunningham $\mathrm{J}$, Jen $\mathrm{J}$ and Harris $\mathrm{CC}$ : Childhood exposure to secondhand smoke and functional mannose binding lectin polymorphisms are associated with increased lung cancer risk. Cancer Epidemiol Biomarkers Prev 18: 3375-3383, 2009.

68 Cianchi F, Cortesini C, Bechi P, Fantappiè O, Messerini L, Vannacci A, Sardi I, Baroni G, Boddi V, Mazzanti R and Masini E: Up-regulation of cyclooxygenase 2 gene expression correlates with tumor angiogenesis in human colorectal cancer. Gastroenterology 121: 1339-1347, 2001.

69 Yao H and Rahman I: Current concepts on the role of inflammation in COPD and lung cancer. Curr Opin Pharmacol 9: 375-383, 2009.

70 Amos CI, Wu X, Broderick P, Gorlov IP, Gu J, Eisen T, Dong Q, Zhang Q, Gu X, Vijayakrishnan J, Sullivan K, Matakidou A, Wang Y, Mills G, Doheny K, Tsai YY, Chen WV, Shete S, Spitz MR and Houlston RS: Genome-wide association scan of tag SNPs identifies a susceptibility locus for lung cancer at $15 \mathrm{q} 25.1$. Nat Genet 40: 616-622, 2008.

71 Hung RJ, McKay JD, Gaborieau V, Boffetta P, Hashibe M, Zaridze D, Mukeria A, Szeszenia-Dabrowska N, Lissowska J, Rudnai P, Fabianova E, Mates D, Bencko V, Foretova L, Janout V, Chen C, Goodman G, Field JK, Liloglou T, Xinarianos G, Cassidy A, McLaughlin J, Liu G, Narod S, Krokan HE, Skorpen F, Elvestad MB, Hveem K, Vatten L, Linseisen J, ClavelChapelon F, Vineis P, Bueno-de-Mesquita HB, Lund E, Martinez C, Bingham S, Rasmuson T, Hainaut P, Riboli E, Ahrens W, Benhamou S, Lagiou P, Trichopoulos D, Holcátová I, Merletti F, Kjaerheim K, Agudo A, Macfarlane G, Talamini R, Simonato L, Lowry R, Conway DI, Znaor A, Healy C, Zelenika D, Boland A, Delepine M, Foglio M, Lechner D, Matsuda F, Blanche H, Gut I, Heath S, Lathrop M and Brennan P: A suscepyibility locus for lung cancer maps to nicotinic acetylcholine receptor subunit genes on 15q25. Nature 452: 633-37, 2008 .

72 Thorgeirsson TE, Geller F, Sulem P, Boffetta P, Hashibe M, Zaridze D, Mukeria A, Szeszenia-Dabrowska N, Lissowska J, Rudnai P, Fabianova E, Mates D, Bencko V, Foretova L, Janout V, Chen C, Goodman G, Field JK, Liloglou T, Xinarianos G, Cassidy A, McLaughlin J, Liu G, Narod S, Krokan HE, Skorpen F, Elvestad MB, Hveem K, Vatten L, Linseisen J, ClavelChapelon F, Vineis P, Bueno-de-Mesquita HB, Lund E, Martinez C, Bingham S, Rasmuson T, Hainaut P, Riboli E, Ahrens W, Benhamou S, Lagiou P, Trichopoulos D, Holcátová I, Merletti 
F, Kjaerheim K, Agudo A, Macfarlane G, Talamini R, Simonato L, Lowry R, Conway DI, Znaor A, Healy C, Zelenika D, Boland A, Delepine M, Foglio M, Lechner D, Matsuda F, Blanche H, Gut I, Heath S, Lathrop M and Brennan P: A variant associated with nicotine dependence, lung cancer and peripheral arterial disease. Nature 452: 638-642, 2008.

73 Wilk JB, Shrine NR, Loehr LR, Zhao JH, Manichaikul A, Lopez LM, Smith AV, Heckbert SR, Smolonska J, Tang W, Loth DW, Curjuric I, Hui J, Cho MH, Latourelle JC, Henry AP, Aldrich M, Bakke P, Beaty TH, Bentley AR, Borecki IB, Brusselle GG, Burkart KM, Chen TH, Couper D, Crapo JD, Davies G, Dupuis J, Franceschini N, Gulsvik A, Hancock DB, Harris TB, Hofman A, Imboden M, James AL, Khaw KT, Lahousse L, Launer LJ, Litonjua A, Liu Y, Lohman KK, Lomas DA, Lumley T, Marciante KD, McArdle WL, Meibohm B, Morrison AC, Musk AW, Myers RH, North KE, Postma DS, Psaty BM, Rich SS Rivadeneira F, Rochat T, Rotter JI, Artigas MS, Starr JM, Uitterlinden AG, Wareham NJ, Wijmenga C, Zanen P, Province MA, Silverman EK, Deary IJ, Palmer LJ, Cassano PA, Gudnason V, Barr RG, Loos RJ, Strachan DP, London SJ, Boezen HM, Probst-Hensch N, Gharib SA, Hall IP, O'Connor GT, Tobin MD and Stricker BH: Genome-wide association studies identify CHRNA5/3 and HTR4 in the development of airflow obstruction. Am J Respir Care Med 186: 622-632, 2012.

74 Bose A, Guilherme A, Huang S, Hubbard AC, Lane CR, Soriano NA and Czech MP: The v-SNARE VTI1A regulates insulinstimulated glucose transport and ACRP30 secretion in 3T3-Li adipocytes. J Biol Chem 280: 36946-36951, 2005.

75 Filmus J, Capurro M and Rast J: Glypicans. Genome Biol 9: 224, 2008.

76 de Andrade, M, Ebbert JO, Wampfler JA, Miller DL, Marks RS, Croghan GA, Jatoi A, Finke EE, Sellers TA and Yang P: Environmental tobacco smoke exposure in women with lung cancer. Lung Cancer 43: 127-134, 2004.

77 Pao W, Miller V, Zakowski M, Doherty J, Politi K, Sarkaria I, Singh B, Heelan R, Rusch V, Fulton L, Mardis E, Kupfer D, Wilson R, Kris $\mathrm{M}$ and Varmus $\mathrm{H}$ : EGF receptor gene mutations are common in lung cancers from "never smokers" and are associated with sensitivity of tumors to gefitinib and erlotinib. Proc Natl Acad USA 101: 13306-13311, 2004.

78 Rudin CM, Avila-Tang E, Harris CC, Herman JG, Hirsch FR, Pao W, Schwartz AG, Vahakangas KH and Samet JM: Lung cancer in never smokers: molecular profiles and therapeutic implications. Clin Cancer Res 15: 5646-5661, 2009. Doi:10.1158/1078-0432.CCR-09-0377.

79 Suzuki M, Shiraishi K, Yoshida a, Shimada Y, Suzuki K, Asamura $\mathrm{H}$, Furuta $\mathrm{K}$, Kohno $\mathrm{T}$ and Tsuta $\mathrm{K}$ : HER2 gene mutations in non-small cell lung carcinomas: Concurrence with HER2 gene amplification and HER2 protein expression and phosphorylation. Lung Cancer 87: 4-22, 2015.

80 World Health Organization. Guidelines for controlling and monitoring the tobacco epidemic: World Health Organization. 1998.

81 McCarthy WJ, Meza R, Jeon J and Moolgavkar S: Lung cancer in never smokers: Epidemiology and risk prediction models. Risk Anal 32(Suppl 1): S69-S84, 2013

82 Wang Yi, Midthun DE, Wampfler JA, Deng B, Stoddard SM, Zhang $S$ and Yang P: Trends in the proportion of patients with lung cancer meeting screening criteria. JAMA 313: 853-855, 2015 .
83 Toh CK, Gao F, Lim WT, Leong SS, Fong KW, Yap SP, Hsu AA, Eng P, Koong HN, Thirugnanam A and Tan EH: Never smokers with lung cancer: epidemiologic evidence of a distinct disease entity. J Clin Oncol 24: 2245-2251, 2006.

84 Yang P, Cerhan JR, Vierkant RA, Olson JE, Vachon CM, Limburg PJ, Parker AS, Anderson KE and Sellers TA: Adenocarcinoma of the lung is strongly associated with cigarette smoking: Further evidence from a prospective study of women. Am J Epidemiol 156: 1114-1122, 2002.

85 Mitsudomi T and Yatabe Y: Mutations of the epidermal growth factor receptor gene and related genes as determinants of epidermal growth factor receptor tyrosine kinase inhibitors sensitivity in lung cancer. Cancer Sci 98: 1817-1824, 2007.

86 Mok TS, Wu YL, Thongprasert S, Yang CH, Chu DT, Saijo N, Sunpaweravong P, Han B, Margono B, Ichinose Y, Nishiwaki Y, Ohe Y, Yang JJ, Chewaskulyong B, Jiang H, Duffield EL, Watkins CL, Armour AA and Fukuoka M: Gefitinib or carboplatin-paclitaxel in pulmonary adenocarcinoma. N Eng $\mathrm{J}$ Med 361: 947-957, 2009.

87 Chansky K, Sculier JP, Crowley JJ, Giroux D, Van Meerbeeck $\mathrm{J}$, Goldstraw $\mathrm{P}$ and International Staging Committee and Participating Institutions: The International Association for the Study of Lung Cancer Staging Project. Prognostic factors and pathologic TNM stage in surgically managed non-small cell lung cancer. J Thorac Oncol 4: 792-801, 2009.

88 Zhang Y, Kent JW Jr, Olivier M, Ali O, Cerjak D, BroeckelU, Abdou R, Dyer TD, Comuzzie A, Cufran JE, Carless MA, Rainwater DL, GÖring HHH, Blangero J and Kissebah AH:A comprehensive analysis of adiponectin QTLs using SNP association, SNP cis-effects on peripheral blood gene expression and gene expression correlation identified novel metabolic syndrome (MetS) genes with potential role in carcinogenesis and systemic inflammation. BMC Med Genomics 6: 14 (1-15), 2013.

89 Mazieres J, Rouquette I, Lepage B, Milia J, Brouchet L, Guibert $\mathrm{N}$, Beau-Faller $\mathrm{M}$, Validire $\mathrm{P}$, Hofman $\mathrm{P}$ and Fouret $\mathrm{P}$ : Specificities of lung adenocarcinoma in women who have never smoked. J Thorac Oncol 8: 923-929, 2013.

90 Flegal KM, Graubard BI, Williamson DF and Gail MH: Causespecific excess deaths associated with underweight, overweight and obesity. JAMA 298: 2028-2037, 2008.

91 Russo A, Autelitano M and Bisanti L: Metabolic syndrome and cancer risk. Eur J Cancer 44: 293-297, 2008.

92 Lee J-Y, Jeon I, Lee JM, Yoon JM and Park SM: Diabetes mellitus as an independent risk factor for lung cancer: A meta-analysis of observational studies. Eur J Cancer 49: 2411-2423, 2013.

93 Shimizu K, Hirami Y, Saisho S, Yukawa T, Maeda A, Yasuda K and Nakata M: Membrane-bound estrogen receptor- $\alpha$ expression and epidermal growth factor receptor mutation are associated with a poor prognosis in lung adenocarcinoma patients. World J Surg Oncol 10: 141, 2012.

94 Stabile LP, Davis AL, Gubish CT, Hopkins TM, Luketich JD, Christie N, Finkelstein S and Siegfried JM: Human non-small cell lung tumors and cells derived from normal lung express both estrogen receptor alpha and beta and show biological responses to estrogen. Cancer Res 62: 2141-2150, 2002.

95 Marquez-Medina D, Gasol-Cudós A, Taberner-Bonastre MT, Samamé Pérez-Vargas JC, Salud-Salvia A and Llombart-Cussac A: Human papillomavirus in non-small-cell lung cancer: the impact of EGFR mutations and the response to erlotinib. Arch Bronconeumol 49: 79-81, 2013. 
96 Liu Y, Inoue M, Sobue T and Tsugane S: Reproductive factors, hormone use and the risk of lung cancer among middle-aged never-smoking Japanese women: a large scale population-based cohort study. Int J Cancer 117: 662-666, 2005.

97 Subramanian J and Govindan R: Lung cancer in never smokers: a review. J Clin Oncol 25: 561-570, 2007.

98 Schabath MB, Wu X, Vassilopoulou-Sellin R, Vaporciyan AA and Spitz MR: Hormone replacement therapy and lung cancer risk: A case-control analysis. Clin Cancer Res 10: 113-123, 2004.

99 Murata C, Watanabe T, Furuya H, Sugioka Y, Mikurube H, Yokoyama A, Atsumi Y, Matsuoka $\mathrm{K}$ and Okazaki I: Aldehydedehydrogenase 2 and $\beta 3$-adrenergic receptor gene polymorphisms: Their association with elevated liver enzymes and metabolic syndrome. Metabolism 52: 1096-1101, 2003.
100 Zanetti KA, Wang Z, Aldrich M, Amos CI, Blot WJ, Bowman ED, Burdette L, Cai Q, Caporaso N, Chung CC, Gillanders EM, Haiman CA, Hansen HM, Henderson BE, Kolonel LN, Marchand LL, Li S, McNeill LH, Ryan BM, Schwartz AG, Sison JD, Spitz MR, Tucker M, Wenzlaff AS, Wiencke JK, Wilkens L, Wrensch MR, Wu X, Zheng W, Zhou W, Christiani D, Palmer JR, Penning TM, Rieber AG, Rosenberg L, Ruiz-Narvaez EA, Su L, Vachani A, Wei Y, Whitehead AS, Chanock SJ and Harris CC: Genomewide association study confirms lung cancer susceptibility loci on chromosomes 5p15 and 15q25 in African-American population. Lung Cancer 98: 33-42, 2016.

Received October 8, 2016

Revised October 30, 2016

Accepted November 3, 2016 